\title{
Female Labour Force Participation in Indonesia: Why Has It Stalled?
}

\author{
Lisa Cameron $^{1}$, Diana Contreras Suarez ${ }^{1}$, William Rowell ${ }^{2}$
}

August 2018

\section{Abstract}

This paper examines the drivers of female labour force participation in Indonesia and disentangles the factors that have contributed to it remaining largely unchanged for two decades at around 51\%. Data from the National Socioeconomic Survey (Susenas) and the Village Potential Statistics (Podes) over the period 1996 to 2013 are used to implement a cohort analysis which separates out life-cycle effects from changes over time in women's labour market participation. We find that the raw labour market participation figures which show little change over time mask changes that offset one another in the current population. There is evidence of social norms changing to support women's participation but this is offset by the effect of the changing industrial structure. Projections show that with the current policy settings Indonesia is unlikely to reach its G20 target of decreasing the gender gap in participation by $25 \%$ between 2014 and 2025 .

Keywords: female labour force participation, labour markets, gender, Indonesia, cohort analysis.

JEL codes: O12, O15, J16, J21.

\footnotetext{
${ }^{1}$ Melbourne Institute of Applied Economic and Social Research, University of Melbourne.

${ }^{2}$ Economic Development Division, Department of Foreign Affairs and Trade.

Funding details - An initial version of this paper was funded by the Department of Foreign Affairs and Trade, Government of Australia, through the Australia-Indonesia Partnership for Economic Governance (AIPEG). The views expressed in this paper are the author's alone and are not necessarily the views of the Australian Government, AIPEG or other partner organisations.
} 


\section{INTRODUCTION}

Indonesia now boasts the largest economy in the Association of Southeast Asian Nations (ASEAN) and the 16th worldwide (ADB 2015). The economy has expanded considerably since the 1970s except when growth halted temporarily during the East Asian financial crisis of 1997-1998. Continued economic development has meant rising average incomes, changes in the sectoral structure of the economy (from agriculture to manufacturing and services), increasing industrialization and urbanization among other changes (Elias and Noone 2011). Despite the significant changes in the Indonesian economy, the impact on the experiences of women in the labour market appears to be rather muted. The 2014 World Development Indicators show $51.4 \%$ of Indonesian women aged 15 and above participating in the labour force (either working or looking for work). This participation rate has remained largely unchanged over the past two decades, the large gap between female and male labour participation continues, and female labour force participation in Indonesia remains low relative to countries at a comparable stage of development in the region (see also ADB, ILO, and IDB 2010).

The main aim of this paper is to identify the drivers of female labour force participation in Indonesia and disentangle how they have contributed to keep female labour force participation unchanged over the period 1996 to 2013. We decompose labour force participation into components on the supply and demand sides of the labour market educational attainment, marital status, fertility, household structure, distance to urban centres, main local industries - and implement a cohort analysis which separates out the effect of life-cycle factors (age) on women's labour market participation and cohort effects (changes in participation over time).

Understanding the constraints that women face in the labour market in Indonesia is essential to informing policies aimed at addressing these constraints to encourage female labour force participation. Previous studies attribute the gender gap in participation to family roles, child-caring and cultural norms in relation to women's traditional roles (Jayachandran 2015). Increases in participation are likely to have flow on effects through female empowerment and so may affect other facets of the gender divide - for example, political representation, having greater say over household decision-making which impacts on female and children wellbeing, and being less accepting of spousal violence. Identifying the drivers of the low female labour force participation is also important to help address constraints facing the Indonesian 
economy. The Indonesian economy is at the point of trying to shift from a pattern of economic growth driven by resources and cheap labour and capital to growth based on high productivity and innovation (ADB 2015). Gender discrimination in the labour market leads to inefficiencies in the allocation of inputs and productivity suffers, World Bank (2012). Increased female labour force participation thus has the potential to be a key contributor to improving the country's productivity, enabling the country to avoid the middle-income trap and continue its economic development into the future. Estimates for Indonesia indicate that increasing Indonesia's female labour force participation to the G20 target of 58.5\% in 2025 would increase annual GDP growth by 0.67 percentage points, corresponding to an increase in GDP of $\$ 123$ billion, or $\$ 432$ per capita in $2025 .^{3}$

Although the raw figures on women's labour market participation show little change over the last two decades, we show that this masks changes which offset one another in the current population. The analysis produces several key results. First, the main drivers of female labour force participation appear to be on the supply side - marital status, educational attainment and the number of children aged between 0 and 2 years of age present in the household. On the demand side, the main source of village income (reflecting the local industrial structure) impacts female labour force participation.

Second, we find that higher education is associated with increases in female labour force participation at young ages while household responsibilities are the main barrier to women participating. Most single and highly educated women have entered the labour market by age 25 and keep participating almost until retirement age. In contrast, women who are married, lowly educated and have children only increase their participation rates after age 40 .

Third, once we control for individual and household characteristics, we find that the underlying propensity for female labour force participation has been increasing over time, despite the lack of change in the aggregate figures. The cohort analysis shows that labour force participation of young females is higher than their older counterparts with similar characteristics at the same age. This is particularly marked in urban areas. If this trend continues, we would expect the aggregate level of female labour force

\footnotetext{
3 Figures compiled by the Australia Indonesia Partnership for Economic Governance, as cited at http://www.bbc.com/indonesia/indonesia-42428508.
} 
participation to increase over time as the older cohorts exit the labour market - although the changing composition of the economy away from the agriculture sector currently works in the opposite direction.

Even with this increase in younger women's labour market participation, the projections from our model show that without considerable policy support, it is unlikely that Indonesia will reach its G20 commitment of reducing the female labour force participation gap by $25 \%$ (to $58.5 \%$ ) by 2025 .

Our findings suggest that policy interventions should be aimed predominantly at the supply side. For example, policies aimed at improving access to tertiary education for girls, particularly in rural areas where education levels remain low, would be likely to increase female labour force participation.

Barriers related to the traditional view of women's role in the household and reflecting expectations such as that a woman leaves the labour force once she is married or has had children, may be more difficult to overcome but our results suggest that there may be some shifts beginning to occur in these cultural norms, particularly in urban areas. Policies supporting married women to re-enter the labour market, especially in urban areas, such as the provision of child care would improve the likelihood of female labour force participation increasing in the future. Strategies that support women working while looking after the family, such as the provision of part-time, family-friendly work, are also likely to help.

The remainder of this paper is organised as follows. The next section discusses the relevant literature on female labour force participation in Indonesia and beyond. This is followed by sections that present the data used and the empirical strategy. We then discuss the empirical findings and use our estimated model to project Indonesia's female labour force participation into the future. The final section concludes and discusses policy implications.

\section{LITERATURE REVIEW}

Unchanged and low female labour force participation despite rapid growth, fertility decline and increased female education attainment is not a phenomenon unique to Indonesia. India has also experienced rapid economic growth and its female labour 
force participation has remained very low at 18\%. Klasen and Pieters (2015) find that the stagnation of female labour force participation in urban India since the 1980's is largely due to an increase in male's education and income; a change in the sectorial structure of the economy where the share of employment in agriculture and manufacturing has decreased which are the sectors that tend to employ more unskilled women; and a decline over time of the positive effect of secondary and tertiary education. Further Afridi et al., (2016) and Andres et al., (2017) study the decline in female labour force participation in India, including rural areas. Using different methodological approaches both find that increasing education levels for married women and men in their household as well as stability in family income are the major contributors to the decline. Countries in the Middle East and North Africa also have low and constant levels of female labour force participation despite increases in female education levels. Gaddis and Klasen (2014) suggest that this pattern can be partially explained by conservative social attitudes towards women's work. In contrast, LatinAmerican countries experienced rapid economic growth during the second half of last century accompanied by significant growth in female labour force participation. The increase in female labour force participation has been attributed to women's increased education levels and reductions in fertility rates, Gasparini et al. (2015). Changes in the sectoral structure of the economy had only small effects on women's participation. There has however been a deacceleration of female labour force participation growth in Latin America in the last two decades.

The empirical literature that focuses on the drivers of female labour force participation in Indonesia is relatively sparse. Schaner and Das (2015) use 21 years of the Indonesian National Labour Force Survey (Sakernas) to identify the barriers to and drivers of female labour force participation. They focus on trends by birth cohort, educational attainment, geography and the type of work (e.g. informal sector, self-employed, employee). They also use the 2012 Indonesia Demographic and Health Survey to examine the correlations between female labour market outcomes and proxies of empowerment, household wealth and family structure including fertility. Their main findings are that younger women in urban areas have increased their labour force participation in recent years. This has largely been achieved by wage employment but younger women in rural areas have reduced their labour force participation by opting out of informal/unpaid employment. They also find evidence of within-country U- 
shaped relationships between female labour force participation and education and wealth, suggesting that one reason why female labour force participation has remained constant despite large gains in income and educational attainment is that the growth in female labour force participation at the top of the income and education distribution has largely been offset by losses at the bottom of the distribution. Child care responsibilities are another factor that limits women's engagement in the labour market. Women with young children are significantly less likely to work relative to their childless peers. Women appear to re-enter the labour force as their children get older either by performing family work or engaging in self-employment but there is no re-entry into wage employment as children age. Finally, they find that wage jobs are preferred among women but they are predominantly held by highly educated women in urban areas.

Feridhanusetyawan and Aswichayono (2001) examine the changing patterns of male and female labour force participation and earnings in Indonesia from 1986 to 1997 using Sakernas data. Their main finding is that with time women were staying in the labour market longer over this period. They find an inverse U-shaped relationship between labour force participation and age. While at the beginning of the period the turning point for women was earlier than for men, by the end of the 1990s, the peakages for males and females were similar. Education played a significant role in determining labour force participation especially in urban areas, and the effects were stronger for females than males early in the period. But by the late 1990s the effects were similar for males and females. They found that the probability of a woman entering the labour market declines significantly if she is married or has more dependent children in the family. But for men being married and having more dependent children increases the probability of entering the labour market.

Comola and de Mello (2009) examined the determinants of employment and earnings for the labour market in Indonesia. They estimate a multinomial logit model to estimate labour market status (e.g. unemployed, employed in the formal sector, or employed in the informal sector) on Sakernas data for 1996 and 2004. Their focus is not explicitly on gender but they find that women living in a household with a high dependency ratio are less likely to have a formal-sector job and more likely to be inactive than those in a low dependency household. Women's labour force participation declines during their most fertile years. Van Klaveren, Tijdens, Hughie-Williams, and Martin (2010) show 
that while male labour market participation is highest in the age range of 35-49 years, for females it is highest in the post-child-rearing years (ages 45-59).

Cepeda (2013), in an analysis for the World Bank, uses information from the 2009 Sakernas to show that single women aged 15 to 24 have the highest rate of participation compared to other marital categories in this age range. The aggregate drop in participation on marriage in this age range is an enormous 37.7 percentage points. Interestingly the biggest drop is among married women without children, and after the first child the reduction decreases per each additional child. One of the suggested explanations for this is an anticipatory effect. As women get married they expect to have children immediately so they stop working even before pregnancy. From age 25 to 64 divorced and widowed women with children are the ones with the highest labour force participation.

Alisjahbana and Manning (2006) show that women's labour force participation decisions reflect a combination of marital and socio-economic status. Poorer married women are more likely to participate than married women in non-poor households.

We contribute to this literature in three ways. First, we conduct the first cohort analysis of female labour force participation in Indonesia of which we are aware. Schaner and Das (2015) examine raw cohort effects but do not control for correlates of female labour force participation (which are changing over time). By controlling for a wide array of determinants on the demand and supply side of the labour market, we are able to observe whether female labour force participation is increasing over time, other things equal. This allows us to make deductions about trends in social norms. The cohort analysis also allows us to isolate the trajectory of labour force participation over an average woman's lifecycle. Second, we conduct our analysis using a different data set than previous studies- the National Socio-economic Survey - which allows us to more accurately control for the role of child-bearing than in previous studies that have examined changes over time. Finally, we present a projection of the female labour force participation and the probability of Indonesia reaching its G20 commitment.

\section{DATA}

The data used in this paper come from two sources - the National Socioeconomic Survey (Susenas) and the Village Census (Podes). 
The Susenas is a nationally representative survey conducted annually and typically covering about 200,000 households. Each survey contains a core questionnaire which consists of a household roster listing the sex, age, marital status, and educational attainment of all household members. ${ }^{4}$ It also includes questions on labour market activity, health, fertility, and other household characteristics.

One of the advantages of the Susenas data set (over the more widely used National Labour Force Survey, Sakernas) is that it collects information on all household members. Using the household roster, we can identify the number of children present in the household and their ages, which allows us to explore the role of child-raising and the availability of alternative child-carers in the household (primarily grandparents and other women who could act as babysitters) in the decision to participate. ${ }^{5} \mathrm{We}$ supplement the Susenas data with data from the Podes. This is a census of all villages across Indonesia (approximately 65,000) conducted three-yearly. We use the Podes for information on some demand side characteristics of the labour market such as the distance to the nearest district office (to act as a proxy for access to jobs) and the main source of income of the village. ${ }^{6}$

The available data allow us to control for the following characteristics that could impact on female labour force participation.

- At the individual level, we control for if the individual is the household head, marital status (e.g. married, divorced, widowed or single), and the level of education completed by the individual (e.g. if the individual completed primary school, lower secondary school, upper secondary school, or tertiary education).

\footnotetext{
${ }^{4}$ This core questionnaire is supplemented by modules covering about 60,000 households which collect additional information such as health care and nutrition, household income and expenditure, and labour force experience.

${ }^{5}$ The Sakernas only identifies the number of children aged under 10 in a household.

${ }^{6} \mathrm{We}$ extract the distance to nearest district office from the 2011 Podes. The main source of village income is likely to change over time due to the changing composition of the Indonesian economy so for this Podes variable we merge the Podes data to the closest year of the Susenas data. For 1996, 2000 and 2011 we match the Podes with the corresponding year of the Susenas. For the 2007 Susenas, we merge with the 2008 Podes because there is no Podes for that particular year. In 2013, we use the information from the 2011 Podes as this is the closest year. However, the 2013 Susenas does not include the unique village identifiers which are available in other years. The smallest geographical unit reported is district so we calculate the main income source at the district level using Podes 2011 and merge it to the 2013 Susenas data. As a robustness check, we re-estimated our main results excluding the 2013 data. The results were similar so the 2013 data was retained for the estimation.
} 
- At the household level, we control for the number of people living in the household, the number of females aged between 45 and 65 years in the household (excluding the female respondent) who are potential babysitters, the number of elderly (defined as greater than or equal to 65 years of age) women and men in the household and the number of children in the household by age (the age groupings are 0 to 2 years of age, 3 to 6,7 to 11 , and 12 to 17).

- At the village level, we control for distance to the nearest district office and the main source of village income. We also control for provincial unemployment rates (calculated from the Susenas) to act as a proxy for the underlying economic conditions at that time.

A disadvantage of the Susenas is that it is cross-sectional so we cannot observe the same individuals or households across time. (This is true also of the Sakernas.) But by using the Susenas from 1996, 2000, 2007, 2011 and 2013 survey years, we can observe how the participation of different birth cohorts (groups of people born in the same years) change over time and lifecycle (age) effects. ${ }^{7}$

\section{METHODOLOGY}

To estimate the determinants of female labour force participation we regress whether an individual participates in the labour force or not $\left(y_{i}=0 / 1\right)$ on a set of potential drivers $\left(x_{i}\right)$ using a probit model. That is, we estimate:

$$
y_{i}=\beta_{0}+\sum_{j=1}^{k} \beta_{j} x_{j i}+\varepsilon_{i}
$$

The vector of potential drivers $\left(x_{i}\right)$ includes those discussed above. Whether a woman works or not reflects her labour supply decision and whether there is any demand for her labour. We thus control for factors on both the supply and demand side of the labour market. On the supply side of the labour market we control for variables that affect women's reservation wages. These variables capture the trade-off between leisure and consumption of other goods (including childcare). Specifically, we control for the highest level of education completed, marital status, if the individual is the household

\footnotetext{
${ }^{7}$ The years used reflect the data to which we had access and our desire to span a reasonably long period of time. The most recent data that we had at that time was 2013 but 2013 Susenas does not provide village codes (see footnote 4) so we also included another year close to 2013 (2011) to which we could merge the PODES data more accurately. As the financial crisis occurred in 1998, we included a year before (1996) and after the crisis (2000) and not a year close to the crisis year. We then chose a year roughly in the middle of the period (2007).
} 
head, household size, the presence of a babysitter or elderly men or women in the household and the number of children at certain ages. On the demand side, we include distance to the nearest district office and the main source of income in the village. We also control for geographic differences using province dummies and the unemployment rate for each province.

Intuitively, the regression identifies the relationship between the control variable and labour force participation. The magnitude of the effect is captured by the coefficient on the control variable $\left(\beta_{\mathrm{j}}\right)$.

In subsequent estimations, dummy variables are also included for the age of the individual at the time of the survey and their year of birth. The age and cohort analysis will establish whether the younger cohorts behave differently in relation to labour force participation compared to their older counterparts and the extent to which the propensity to participate in the labour market has changed over time. The coefficients (and associated marginal effects) on the age dummies capture how an individual's likelihood of participating varies across the life-cycle, irrespective of their year of birth after controlling for other characteristics. The coefficients on the year of birth dummy variables allows us to compare people born in different years and so identify whether the younger cohorts behave differently in relation to labour force participation than their older counterparts. ${ }^{8}$ One well-known problem in the estimation of age, cohort and year effects is that identification of all three types of effects is not possible, as they are perfectly collinear (year of birth + age $=$ survey year). To overcome this problem we use a proxy variable approach following Euwals et al., (2011). We capture the year effect by including a continuous variable that varies across years - the provincial unemployment rate. ${ }^{9}$

We estimate equation (1) separately for men and women and disaggregated by rural and urban status. ${ }^{10}$

\footnotetext{
${ }^{8}$ We use 49 age dummies covering from 15 to 64 years of age (the omitted category is 15 years of age) and 49 cohort dummies - one for each year of birth from 1943 to 1992 (the omitted category is someone born in 1943).

${ }^{9}$ Another approach is to omit the year/period effect under the assumption that its effect is negligible. For example, Goldin \& Mitchell (2017) argue that if period effects influence all individuals in a year, independent of their age, then the cohort and life-cycle effects will dominate.

${ }^{10}$ Results estimated separately for Java-Bali and the Outer Islands are presented in the appendix.
} 


\section{RESULTS}

\section{Descriptive Results}

Table 1 presents the summary statistics of labour force participation and the explanatory variables for urban and rural areas. At the individual level, there is a substantial gap between female and male labour force participation - female labour force participation is on average 33 percentage points (approximately 40\%) less than male participation ( $85 \%$ compared to $52 \%$ ). The participation rates also tend to be higher in rural areas compared to urban areas for both men and women. Most household heads are males, and most females and males are married. At the household level, there are more potential babysitters in households in urban areas, possibly due to higher housing prices. At the village level, the distances to nearest district office are unsurprisingly less in urban areas and agriculture is most prevalent in rural areas compared to urban areas where services and large trade/retail represent large income sources.

Table 2 disaggregates the summary statistics by survey year. The key results are that the gender gap in labour force participation remains largely unchanged over the period (see also Figure 1). Educational attainment has increased over time, with women's educational attainment increasing more than men's. Household size has been shrinking over time, and the average number of children per household has been declining. Finally, the unemployment rate shows a downward trend from 1996 to 2013.

Now looking at differences with age, Table 3 shows that labour force participation is lowest in the 15-29 age group. This is likely due to these individuals still being in school or completing higher levels of education. The proportion of those who are household heads follows a similar trend. Nearly half of all women aged 15 to 29 years are married and this increases to around $90 \%$ for those aged 30 to 44 years. This decreases to $75 \%$ for women aged 45 to 64 years as the proportion of widowers increases by a commensurate amount. Lastly, in terms of educational attainment, while there is a clear gender gap in education attainment for the older age groups, there is no gender gap between males and females in the youngest cohorts. There is a greater share of females completing tertiary education than males. 


\section{Estimation Results}

Table 4 presents the results of estimating equation (1) for men and women by rural and urban status. For ease of interpretation we present marginal effects which are interpreted as the percentage point change in the probability of the individual participating in the labour market associated with a one unit change in that explanatory variable. Marital status is a key correlate of labour force participation for women. A married woman in rural areas is 11 percentage points less likely to be working or looking for work than a single woman and this difference is statistically significant. This association is more pronounced for married women in urban areas as they are 24 percentage points less likely to be participating than single women.

Being a household head for both men and women increases the likelihood of labour force participation in both urban and rural areas. But the magnitude of the association for men is substantially smaller because men are generally the primary income earners so largely work irrespective of whether they are the household head or not. The level of educational attainment is also a strong correlate of female labour force participation. Women who complete upper secondary school are more likely to participate compared to women who only complete lower secondary, by about 8 percentage points in both rural and urban areas. The likelihood of participating dramatically increases again if women attain the next education level (tertiary education). But for men there is little variation in the probability of participating with different levels of education. Men, as the main bread winners in Indonesian society tend to work, regardless of their level of education.

Household size is associated with decreased participation for women in rural areas -an increase in household size of one decrease the likelihood of participation by nearly 2 percentage points. But the magnitude of the associations for urban females and males are much closer to zero. The presence of another woman aged 45-65 years in the household or an elderly female or male in the household is significantly associated with an increase in the likelihood of female participation by around 1 to 3 percentage points. This may reflect the ability of the woman to leave children at home with an adult. This effect is negligible for men. The presence of children in the household also has markedly different effects for men and women. For women, the presence of young children is associated with a decrease in the likelihood of participating. The presence of a child under two years of age is associated with a decrease in the probability of 
participation by 8 percentage points but only a small (and positive) change in men's labour market activity.

On the demand side of the labour market, we hypothesised that the coefficient for distance to the nearest district office would be negative as it was intended to capture distance to an active labour market, however, the coefficient is positive, albeit small. The variable could be positively correlated with agricultural employment in rural areas, with the positive coefficient reflecting women's greater involvement in agriculture. The villages' main sources of income variables show that female participation is highest in areas with agriculture and industry (which includes manufacturing). But as the economy moves further away from agriculture to other sectors, female participation drops.

The results for Java-Bali and Outer Islands follow a similar pattern to those presented in Table 4 and are presented in Table A-1 in the appendix.

We re-estimate the model for each year of the Susenas separately to determine if the correlates of labour force participation have changed across time. The marginal effects for each year are presented in the appendix - see Table A-2. This analysis shows that most of the correlates of female labour force participation (both the direction and magnitude of their impact) remain largely unchanged over time. These include if the individual is the household head or a widower, has a low level of education, the presence of elderly females and males in the household and the number of young children in the household. ${ }^{11}$

There are however a number of interesting changes in the correlates of female labour force participation over the period. In 1996, married women were around 23 percentage points less likely to participate than their single counterparts. By 2013, the negative association for women between being married and labour force participation decreased to around 14 percentage points. The relationship between gender and industrial structure has also changed. Villages that have large trading or retail as their main source of income have become associated with higher levels of female labour force

\footnotetext{
${ }^{11}$ The effect of upper secondary and tertiary education on labour market participation drops between 1996 and 2000. This likely reflects the result of the financial crisis in 1998 which disproportionately affected better educated workers. The high unemployment rates among higher educated workers in 2000 may have caused some highly educated workers to withdraw from the labour force.
} 
participation over time. In 1996, villages that had large trading or retail as their main income source had lower female participation than those whose main source of income came from agriculture by about 10 percentage points. But by 2013 the penalty for female labour force participation of such income sources had decreased to be only around 2 percentage points, suggesting women were starting to be accommodated in these industries.

\section{Age and Cohort Results}

The descriptive results showed that the raw female labour force participation figures have largely remained unchanged over the survey years. This section examines the results by age and cohort to enable us to understand the extent of changes in participation across the life-cycle and/or changing attitudes by younger cohorts towards participation that may keep the aggregate figures unchanged, while still controlling for the characteristics included in the previous section.

The results for males and females are shown below in Figure $2 .{ }^{12}$ Conditional on all other explanatory variables, the results of the age analysis are largely as anticipated. Female labour force participation increases quickly up until around 25 years of age before slowing over the ages typically associated with child bearing. It peaks at around 45 years of age before starting to decline. The contrast with males shows the extent of the disparity across these years. Men's participation rises sharply to almost $100 \%$ once the period of educational attainment is over and remains constant before starting to decrease from age 50 .

The analysis of age effects shows the extents to which women's decision to work are affected by their child-rearing responsibilities. Figure 3 compares the age analysis for Indonesia to a similar analysis conducted for the Netherlands (taken from Euwals et al., 2011). Notwithstanding the cultural and other country differences, the figures show that there is a much larger decrease in women's labour force participation during the child bearing years in Indonesia than in the Netherlands. There is no discernible drop associated with the child-bearing years in the Netherlands (once the number of children and other explanatory variables are controlled for). Female labour force participation

\footnotetext{
${ }^{12}$ The sample averages of the explanatory variables are applied to the regression coefficients and added to the age and cohort effects to present the impact of different ages and cohorts on labour force participation.
} 
in the Netherlands reaches its peak of about $70 \%$ at age 26 . In contrast, in Indonesia women's labour force participation at age 26 is about 15 percentage points below its peak (55\% compared to the $70 \%$ it reaches at age 45$)$.

The cohort effects plotted in Figure 2 reveals some interesting findings. They show that, other things equal, female labour force participation has been increasing from around $40 \%$ for those born in the 1940 s to around $60 \%$ for those born most recently in the 1980 s and early 1990s. Male labour force participation has remained at about $95 \%$ across the cohorts.

The cohort analysis thus reveals a large increase in the underlying propensity for women to participate in the labour force. This may reflect changing cultural norms. If this cultural shift continues overtime, as the older cohorts exit the labour market we would expect to eventually see an increase in female labour force participation. This increase seems to level off for the younger cohorts with no increases apparent after the 1973 cohort (aged 40 in 2013) and dropping from the 1983 cohort. The reason for this is unclear, it may in part reflect increases in the educational attainment of younger cohorts with young people still completing their education. Figure 4 shows that this is largely a rural phenomenon. The percentage of individuals in rural areas who were born since 1983 and who have a tertiary education rose from $1.4 \%$ in 1996 to $7.9 \%$ in 2013.

Figures 4 and 5 present the results for rural and urban areas respectively. Some differences emerge. The age profile for younger urban females is lower than for their rural counterparts. This probably reflects the higher educational attainment in urban areas delaying their entry into the labour market. There is also a sharp decline in the male age profile at around 55 years of age. Unlike rural areas where the decline in male labour force participation is gradual, in urban areas this is particularly pronounced. The current legislated retirement age in Indonesia is 55. This effect is more pronounced in urban areas as a result of there being more formal sector jobs.

The cohort effects for women show greater differences between rural and urban areas. There have been larger increases in young women's labour force participation in urban areas than rural areas. The labour force participation of the older cohorts in urban areas is estimated at around $28 \%$ and more than doubles at close to $60 \%$ for the youngest cohorts. The increase in rural areas is much smaller but starts from a higher base 
(increasing from $45 \%$ to $62 \%$ ). This is again consistent with changing cultural norms and women beginning to be accepted into non-agricultural employment in urban areas.

Figures A-1 to A-4 in the appendix disaggregate the age and cohort effects further into their respective Java-Bali and Outer Island regions. The findings are largely consistent across the different regions.

The appendix further disaggregates the age and cohort effects for women by marital status, level of educational attainment and the number of children in various age categories in the household and the villages' main sources of income (see Figures A-5, A-6, A-7 and A-8). Figure A-5 shows that labour force participation increased for both marred and unmarried women in the younger cohorts. This suggests that the change in attitudes towards female labour force participation is not hindered by traditional roles related to marital status. ${ }^{13}$

Younger cohorts across all levels of educational attainment have increased their labour force participation compared to the older cohorts, except participation by uppersecondary-educated women which has remained constant (Figure A-6). Figure A-7 shows that female labour force participation increased for all women, regardless of the age of the children in the household (although less for women in households with children under the age of two years, and not much for birth cohorts since the late 1970s). Figure A-8 shows that female labour force participation among the younger cohorts from villages with processing/industry, large trading/retail and services as their main source of income has increased relative to their older counterparts. ${ }^{14}$ Younger cohorts from agricultural villages have also increased their labour force participation but not to the same extent as the other sectors given that female labour force participation was

\footnotetext{
${ }^{13}$ The age effect also shows the considerable difference between married and not married females - for not married females, labour force participation reaches its peak by the age of 25 years old (similar to the age effect in the Netherlands as presented in Figure 3) but for married females it takes until around 50 years of age for labour force participation to reach its peak.

An alternative modelling approach would be to run a Oaxaca decomposition of the changes in female labour force participation between 1996 and 2013. This would allow an identification of what characteristics are associated with increased participation. Such an analysis shows increases in participation by married women are predominantly driving the changes across time, ceteris paribus.

${ }^{14}$ Mining/quarrying also show improvement across the younger cohorts but the variability in these results and the age effect are likely due to the smaller sample size of females in this sector. For example, there are only 7,795 observations for this sector compared to 47,312 observations for processing/industry sector or 123,007 observations in the large trading/retail sector.
} 
already quite high in the older cohorts in agricultural villages. However, this has stalled for cohorts born after 1970 .

\section{FEMALE LABOUR FORCE PARTICIPATION PROJECTIONS}

The G20 countries' commitment to decrease the female/male labour market participation gap in 2014 by $25 \%$ by 2025 , means that Indonesia will need to increase its female labour force participation (FLFP) to $58.5 \%$. This goal will be challenging to achieve given that women's labour force participation in Indonesia has remained constant at just over $50 \%$ for the last two decades. However, the analysis above identified an increasing underlying propensity for women to participate in the labour market once other factors, such as changes in industrial structure, education and household composition, are controlled for. This section presents projections of female labour force participation to 2025.

We first examine how well the model predicts FLFP by comparing the values predicted by the model with the observed levels in the raw data. We then estimate the rate of growth of each of the variables that determine FLFP in our model and use these to project FLFP through to 2025 . We examine the sensitivity of our results to alternative scenarios and then conclude.

Using the estimated coefficients in equation 1, we calculate the predicted values of FLFP within the sample period and compare the result to the observed values. ${ }^{15}$ Figure 6 plots the actual and predicted values of female labour force participation. The model performs relatively well with the predicted value being close to the observed value, except in 2000 where the actual value dips from trend. The predicted trend between 1996 and 2007 is steeper that the trend after 2007.

In order to predict the values of FLFP up to 2025, we need to make assumptions about the values of the variables that determine FLFP (e.g. level of education, industrial structure, age composition). We use a very simple trend-time series model to predict the value of all the determinants up to 20 years ahead following equation 2 which we estimate using data from 1996 to 2013.

\footnotetext{
15 To calculate a national FLFP we estimate the model over both urban and rural samples, including a control for urban areas. Results are presented in Table A3 in the appendix.
} 


$$
X_{i}=\alpha_{0}+\alpha_{1} t+\varepsilon_{i}
$$

where $t$ takes the value of 1 in 1996, 5 in 2000, 12 in 2007, 16 in 2011 and 18 in 2013; and $\varepsilon$ is the random error term. Table 5 shows the estimated percentage point growth for each of the variables. In terms of education, this model predicts that each year the proportion of women with primary school education will decrease 0.0043 percentage points while the proportion of women with tertiary education or more will increase by 0.0032 percentage points annually. The proportion of people living in urban areas is forecast to increase by 0.0073 percentage points each year.

In order to apply the estimated life cycle effects (coefficients on age dummies) we also project the distribution of women across age groups. We assume that the proportion of people living in each province remains constant. ${ }^{16}$

We present two projections. The most optimistic projection assumes that trends in underlying variables observed between 1996 and 2013 will continue. The second, more pessimistic projection, reflects the fact the growth in FLFP flattens off after 2007 (see Figure 1), and so uses only data from 2007 to 2013 to project into the future.

Figure 7 presents the results of both scenarios. The red line between 1996 and 2015 shows the observed levels. The green triangles show the official BPS estimated figures. The orange dotted line represents the optimistic scenario and the blue dashed line represents the more pessimistic scenario. Under the optimistic scenario FLFP just reaches the $58.5 \%$ target by 2025 . It is forecast that FLFP will reach $59 \%$ by 2025 . Under the less optimistic scenario the FLFP will remain almost constant through to 2025 with FLFP decreasing slightly by $2025 .^{17}$

\section{SUMMARY AND POLICY IMPLICATIONS}

Female labour force participation in Indonesia has remained relatively constant from 1996 to 2013 even in the face of dramatic economic change. The analysis in this paper however suggests that once you control for individual, household and village

\footnotetext{
${ }^{16}$ We compared our projected figures for the percentage of population by age group against UN forecasts. They are broadly similar. Our projected urbanisation rate also is in a similar range to the UN's.

${ }^{17}$ Note that both the predictions indicate an increase over the official BPS FLFP estimate for 2015. The BPS uses Sakernas information to calculate FLFP.
} 
characteristics, there are signs that the underlying propensity for women to participate in the labour force has been increasing, particularly in urban areas. This is an interesting result and is consistent with societal attitudes changing to be more accommodating of women participating in the labour market. Offsetting this secular increase in women's labour force participation are decreases in participation as a result of the lesser importance of agriculture. If the underlying propensity for women to participate continues to increase then as the older cohorts exit the labour market, we would expect female labour force participation to increase in the long run (once the employment share of agriculture has stabilised).

We nevertheless find in the shorter term the G20 target of 58.5\% female labour force participation by 2025 is unlikely to be reached. Our projections show that the target will only just be reached under our most optimistic scenario. The less optimistic (and arguably more realistic) scenario suggests that the FLFP may even decrease by 2025 if the most recent trends continue.

The main drivers of female labour force participation (cohort and age effects aside) were found to be marital status, the number of children aged between 0 and 2 years of age in the household, educational attainment (particularly tertiary education) and the village industrial structure (with agriculture and manufacturing being female-friendly industries).

Our results have several policy implications. That marital status and the presence of young children have such a large negative impact on female labour force participation suggests that policies that support women to return to work after child birth are likely to increase female labour force participation. These policies include the provision of some form of child-care for women with young children and policies and laws that encourage employers to make part-time and family-friendly work available. Increasing the educational attainment of women, particularly in rural areas where educational attainment remains low, is also likely to assist.

That the cohort analysis finds that the underlying propensity for women to participate in the labour markets is increasing is promising. However, the ongoing movement of the Indonesian economy away from the agricultural sector, given the importance of the agricultural sector to female employment, will continue to offset this effect for some time. Thus, policies designed to provide women with access to employment in non- 
traditional industrial sectors, for example, through the provision of subsidised vocational education and/or campaigns that provide and promote opportunities for women in these sectors, are also worthy of attention. 


\section{REFERENCES}

Afridi, Farzana, Taryn Dinkelman, and Kanika Mahajan. 2016. "Why are Fewer Married Women Joining the Work Force in India? A Decomposition Analysis over Two Decades?” IZA Discussion Papers, 9722.

Alisjahbana, Armida, and Chris Manning. 2006. "Labour Market Dimensions of Poverty in Indonesia." Bulletin of Indonesian Economic Studies, 42(2), 235-261. doi: 10.1080/00074910600873674.

Andres, Luis, Basab Dasgupta, George Joseph, Vinoj Abraham, and Maria Correia. 2017. "Precarious Drop: Reassessing Patterns of Female Labor Force Participation in India." World Bank Group, Policy Research Working Papers, 8024.

Asian Development Bank. 2015. "Indonesia Factsheet”, Mandaluyong City, Philippines: Asian Development Bank, 24 April, $<$ http://www.adb.org/publications/indonesia-fact-sheet $>$

Asian Development Bank. 2013. "Gender Equality in the Labor Market in the Philippines.” Mandaluyong City, Philippines: Asian Development Bank, 2013.

Asian Development Bank, International Labour Organization and Islamic Development Bank. 2010. "Indonesia: critical development constraints." Mandaluyong City, Philippines: Asian Development Bank.

Cepeda, Laura. 2013. Gender Wage Inequality in Indonesia. Poverty and Social Protection Cluster, World Bank, Aug 1.

Comola, Margherita and Luiz de Mello. 2009. "The Determinants of Employment and Earnings in Indonesia - A Multinomial Selection Approach." Economics Department Working Paper - OECD, no. 690.

Elias, Stephen and Clare Noone. 2011. "The Growth and Development of the Indonesian Economy." Reserve Bank of Australia Bulletin - December Quarter .

Euwals, Rob, Marike Knoef, and Daniel van Vuuren, 2011. "The Trend in Female Labour Force Participation: What Can Be Expected for the Future?" Empirical Economics, 40(3), 729-753.

Feridhanusetyawan, Tubagus and Haryo Aswicahyono. 2001. "Gender Assessment of the Indonesian Labour Market", East Asian Development Network, No. 9.

Gaddis, Isis and Stephan Klasen, 2014. "Economic Development, Structural Change, and Women's Labor Force Participation.” Journal of Population Economics, 27(3), 639-681. 
Gasparini, Leonardo, Mariana Marchionni, Nicolás Badaracco, and Joaquín Serrano. "Female Labor Force Participation in Latin America: Evidence of Deceleration." Documentos de Trabajo del CEDLAS (2015).

Goldin, Claudia and Joshua Mitchell. 2017. "The New Life Cycle of Women's Employment: Disappearing Humps, Sagging Middles, Expanding Tops.” Journal of Economic Perspectives, 31(1), 161-82.

Islam. Iyanatul and Anis Chowdhury. 2009. "Growth, Employment and Poverty Reduction in Indonesia", International Labour Office (ILO), Geneva.

Jayachandran Seema. 2015. "The Roots of Gender Inequality in Developing Countries." The Annual Review of Economics, 7: 63-88.

Klasen, Stephan and Janneke Pieters. 2015. "What explains the stagnation of female labor force participation in urban India?" The World Bank Economic Review, 29(3), 449-478.

Manning, Chris. 2000 "Labour Market Adjustment to Indonesia's Economic Crisis: Context, Trends and Implications." Bulletin of Indonesian Economic Studies, Vol. 36, No. 1, pp.105-136.

World Bank. 2012. "Towards gender Equality in East Asia and the Pacific." World Bank, Washington DC. 
Table 1. Summary statistics of labour force participation and explanatory variables

\begin{tabular}{|c|c|c|c|c|}
\hline \multirow[b]{2}{*}{ Variables } & \multicolumn{2}{|c|}{ Urban } & \multicolumn{2}{|c|}{ Rural } \\
\hline & Male & Female & Male & Female \\
\hline \multicolumn{5}{|l|}{ Individual characteristics: } \\
\hline Labour force participation & 0.813 & 0.475 & 0.886 & 0.565 \\
\hline Household head & 0.573 & 0.075 & 0.621 & 0.067 \\
\hline Marital status: Single & 0.371 & 0.288 & 0.308 & 0.199 \\
\hline Marital status: Married & 0.611 & 0.634 & 0.670 & 0.718 \\
\hline Marital status: Divorced & 0.009 & 0.026 & 0.010 & 0.026 \\
\hline Marital status: Widowed & 0.009 & 0.052 & 0.012 & 0.057 \\
\hline Education: Primary & 0.213 & 0.237 & 0.368 & 0.364 \\
\hline Education: Lower secondary & 0.231 & 0.227 & 0.199 & 0.170 \\
\hline Education: Upper secondary & 0.360 & 0.301 & 0.159 & 0.113 \\
\hline Education: Tertiary & 0.105 & 0.095 & 0.028 & 0.025 \\
\hline \multicolumn{5}{|l|}{ Household characteristics: } \\
\hline Household size & \multicolumn{2}{|c|}{4.810} & \multicolumn{2}{|c|}{4.697} \\
\hline Number of women aged 45-65 years & \multicolumn{2}{|c|}{0.313} & \multicolumn{2}{|c|}{0.276} \\
\hline Number of elderly females & \multicolumn{2}{|c|}{0.077} & \multicolumn{2}{|c|}{0.076} \\
\hline Number of elderly males & \multicolumn{2}{|c|}{0.065} & \multicolumn{2}{|c|}{0.071} \\
\hline Number of children: 0 to 2 years old & \multicolumn{2}{|c|}{0.223} & \multicolumn{2}{|c|}{0.247} \\
\hline Number of children: 3 to 6 years old & \multicolumn{2}{|c|}{0.309} & \multicolumn{2}{|c|}{0.364} \\
\hline Number of children: 7 to 11 years old & \multicolumn{2}{|c|}{0.423} & \multicolumn{2}{|c|}{0.507} \\
\hline Number of children: 12 to 17 years old & \multicolumn{2}{|c|}{0.663} & \multicolumn{2}{|c|}{0.6750} \\
\hline \multicolumn{5}{|l|}{ Village characteristics: } \\
\hline Distance to nearest district office ('100km) & \multicolumn{2}{|c|}{0.462} & \multicolumn{2}{|c|}{0.788} \\
\hline Main income: Agriculture & \multicolumn{2}{|c|}{0.309} & \multicolumn{2}{|c|}{0.961} \\
\hline Main income: Mining/quarrying & \multicolumn{2}{|c|}{0.011} & \multicolumn{2}{|c|}{0.004} \\
\hline Main income: Processing/industry & \multicolumn{2}{|c|}{0.087} & \multicolumn{2}{|c|}{0.008} \\
\hline Main income: Large trading/retail & \multicolumn{2}{|c|}{0.243} & & \\
\hline Main income: Services other than trade & & & & \\
\hline Unemployment\# & & & & \\
\hline Observations & 469,157 & 481,751 & 681,427 & 691,280 \\
\hline
\end{tabular}

Source: Author's calculations using Susenas and Podes 
Table 2. Summary statistics of labour force participation and explanatory variables over time

\begin{tabular}{|c|c|c|c|c|c|c|c|c|c|c|}
\hline \multirow[b]{2}{*}{ Variables } & \multicolumn{2}{|c|}{1996} & \multicolumn{2}{|c|}{2000} & \multicolumn{2}{|c|}{2007} & \multicolumn{2}{|c|}{2011} & \multicolumn{2}{|c|}{2013} \\
\hline & Male & Female & Male & Female & Male & Female & Male & Female & Male & Female \\
\hline \multicolumn{11}{|l|}{ Individual characteristics: } \\
\hline Labour force participation & 0.854 & 0.507 & 0.832 & 0.477 & 0.865 & 0.542 & 0.860 & 0.550 & 0.857 & 0.547 \\
\hline Household head & 0.572 & 0.053 & 0.574 & 0.061 & 0.605 & 0.073 & 0.625 & 0.081 & 0.625 & 0.084 \\
\hline Marital status: Single & 0.373 & 0.274 & 0.371 & 0.271 & 0.328 & 0.229 & 0.304 & 0.206 & 0.298 & 0.203 \\
\hline Marital status: Married & 0.613 & 0.664 & 0.613 & 0.658 & 0.652 & 0.683 & 0.671 & 0.705 & 0.674 & 0.704 \\
\hline Marital status: Divorced & 0.007 & 0.025 & 0.008 & 0.026 & 0.009 & 0.026 & 0.012 & 0.026 & 0.013 & 0.026 \\
\hline Marital status: Widowed & 0.007 & 0.037 & 0.008 & 0.045 & 0.011 & 0.062 & 0.013 & 0.063 & 0.015 & 0.067 \\
\hline Education: Primary & 0.348 & 0.346 & 0.327 & 0.335 & 0.296 & 0.308 & 0.283 & 0.287 & 0.273 & 0.281 \\
\hline Education: Lower secondary & 0.187 & 0.159 & 0.206 & 0.185 & 0.224 & 0.206 & 0.217 & 0.206 & 0.222 & 0.211 \\
\hline Education: Upper secondary & 0.194 & 0.144 & 0.234 & 0.182 & 0.251 & 0.202 & 0.256 & 0.206 & 0.274 & 0.222 \\
\hline Education: Tertiary & 0.039 & 0.025 & 0.040 & 0.026 & 0.068 & 0.062 & 0.070 & 0.073 & 0.074 & 0.081 \\
\hline \multicolumn{11}{|l|}{ Household characteristics (per household): } \\
\hline Household size & \multicolumn{2}{|c|}{5.108} & \multicolumn{2}{|c|}{4.814} & \multicolumn{2}{|c|}{4.722} & \multicolumn{2}{|c|}{4.563} & \multicolumn{2}{|c|}{4.456} \\
\hline Number of women aged 45-65 years & \multicolumn{2}{|c|}{0.269} & \multicolumn{2}{|c|}{0.283} & \multicolumn{2}{|c|}{0.297} & \multicolumn{2}{|c|}{0.299} & \multicolumn{2}{|c|}{0.311} \\
\hline Number of elderly females & \multicolumn{2}{|c|}{0.078} & \multicolumn{2}{|c|}{0.084} & \multicolumn{2}{|c|}{0.077} & \multicolumn{2}{|c|}{0.071} & \multicolumn{2}{|c|}{0.075} \\
\hline Number of elderly males & \multicolumn{2}{|c|}{0.069} & \multicolumn{2}{|c|}{0.072} & \multicolumn{2}{|c|}{0.070} & \multicolumn{2}{|c|}{0.065} & \multicolumn{2}{|c|}{0.065} \\
\hline Number of children: 0 to 2 years old & & & & & & & & & & \\
\hline Number of children: 3 to 6 years old & & & & & & & & & & \\
\hline Number of children: 7 to 11 years old & & & & & & & & & & \\
\hline Number of children: 12 to 17 years old & & & & & & & & & & \\
\hline Village characteristics (per village): & & & & & & & & & & \\
\hline Distance to nearest district office ('100km) & & & & & & & & & & \\
\hline Main income: Agriculture & & & & & & & & & & \\
\hline Main income: Mining/quarrying & & & & & & & & & & \\
\hline Main income: Processing/industry & & & & & & & & & & \\
\hline Main income: Large trading/retail & & & & & & & & & & \\
\hline Main income: Services other than trade & & & & & & & & & & \\
\hline Unemployment\# & & & & & & & & & & \\
\hline Observations & 219,045 & 230,355 & 174,903 & 179,665 & 325,065 & 328,629 & 345,598 & 347,342 & 85,973 & 87,040 \\
\hline
\end{tabular}

Source: Author's calculations using Susenas and Podes 
Table 3. Summary statistics of labour force participation and individual characteristics by age group

\begin{tabular}{lcccccccc}
\hline & \multicolumn{3}{c}{ Male } & & \multicolumn{3}{c}{ Female } \\
\cline { 2 - 3 } Variables & $\mathbf{1 5 - 2 9}$ & $\mathbf{3 0 - 4 4}$ & $\mathbf{4 5 - 6 4}$ & & $\mathbf{1 5 - 2 9}$ & $\mathbf{3 0 - 4 4}$ & $\mathbf{4 5 - 6 4}$ \\
\hline Labour force participation & 0.700 & 0.980 & 0.938 & & 0.422 & & 0.596 & 0.610 \\
Household head & 0.185 & 0.841 & 0.960 & & 0.020 & 0.056 & 0.183 \\
Marital status: Single & 0.741 & 0.077 & 0.016 & & 0.519 & 0.048 & 0.022 \\
Marital status: Married & 0.253 & 0.903 & 0.939 & & 0.463 & 0.892 & 0.753 \\
Marital status: Divorced & 0.005 & 0.013 & 0.012 & & 0.015 & 0.031 & 0.037 \\
Marital status: Widowed & 0.001 & 0.007 & 0.033 & & 0.003 & 0.029 & 0.188 \\
Education: Primary & 0.295 & 0.306 & 0.320 & & 0.304 & 0.334 & 0.292 \\
Education: Lower secondary & 0.302 & 0.169 & 0.120 & & 0.293 & 0.147 & 0.089 \\
Education: Upper secondary & 0.263 & 0.267 & 0.163 & & 0.243 & 0.196 & 0.088 \\
Education: Tertiary & 0.035 & 0.080 & 0.069 & & 0.049 & 0.068 & 0.040 \\
\hline Observations & 469,998 & 406,980 & 273,606 & & 482,448 & 418,598 & 271,985 \\
\hline
\end{tabular}

Source: Author's calculations using Susenas. 
Table 4. Marginal effects of pooled sample

\begin{tabular}{|c|c|c|c|c|}
\hline \multirow{2}{*}{ Variables } & \multicolumn{2}{|c|}{ Rural } & \multicolumn{2}{|c|}{ Urban } \\
\hline & Female & Male & Female & Male \\
\hline Household head & $\begin{array}{c}0.2109 * * * \\
(0.0031)\end{array}$ & $\begin{array}{c}0.0565 * * * \\
(0.0015)\end{array}$ & $\begin{array}{c}0.1143 * * * \\
(0.0040)\end{array}$ & $\begin{array}{c}0.0370 * * * \\
(0.0021)\end{array}$ \\
\hline \multicolumn{5}{|l|}{ Marital status: Single (omitted) } \\
\hline Marital status: Married & $\begin{array}{c}-0.1068 * * * \\
(0.0025)\end{array}$ & $\begin{array}{c}0.0753 * * * \\
(0.0016)\end{array}$ & $\begin{array}{c}-0.2430 * * * \\
(0.0028)\end{array}$ & $\begin{array}{c}0.1589 * * * \\
(0.0025)\end{array}$ \\
\hline Marital status: Divorced & $\begin{array}{c}0.0101 * * \\
(0.0050)\end{array}$ & $\begin{array}{c}0.0088 * * * \\
(0.0019)\end{array}$ & $\begin{array}{c}0.0156^{* * * *} \\
(0.0058)\end{array}$ & $\begin{array}{c}0.0300 * * * \\
(0.0034)\end{array}$ \\
\hline Marital status: Widowed & $\begin{array}{c}-0.1585 * * * \\
(0.0046)\end{array}$ & $\begin{array}{c}0.0145^{* * * *} \\
(0.0016)\end{array}$ & $\begin{array}{c}-0.1525 * * * \\
(0.0048)\end{array}$ & $\begin{array}{c}0.0493 * * * \\
(0.0025)\end{array}$ \\
\hline \multicolumn{5}{|l|}{ Education: No schooling (omitted) } \\
\hline Education: Primary & $\begin{array}{c}-0.0303 * * * \\
(0.0016)\end{array}$ & $\begin{array}{c}0.0017 * * \\
(0.0007)\end{array}$ & $\begin{array}{c}-0.0215 * * * \\
(0.0026)\end{array}$ & $\begin{array}{c}0.0160 * * * \\
(0.0018)\end{array}$ \\
\hline Education: Lower secondary & $\begin{array}{c}-0.1101 * * * \\
(0.0021)\end{array}$ & $\begin{array}{c}-0.0453 * * * \\
(0.0011)\end{array}$ & $\begin{array}{c}-0.1008 * * * \\
(0.0027)\end{array}$ & $\begin{array}{c}-0.0558 * * * \\
(0.0023)\end{array}$ \\
\hline Education: Upper secondary & $\begin{array}{c}-0.0313 * * * \\
(0.0024)\end{array}$ & $\begin{array}{c}-0.0309 * * * \\
(0.0012)\end{array}$ & $\begin{array}{c}-0.0162 * * * \\
(0.0026)\end{array}$ & $\begin{array}{c}-0.0382 * * * \\
(0.0020)\end{array}$ \\
\hline Education: Tertiary & $\begin{array}{c}0.2745 * * * \\
(0.0032)\end{array}$ & $\begin{array}{c}-0.0095 * * * \\
(0.0022)\end{array}$ & $\begin{array}{c}0.2794 * * * \\
(0.0030)\end{array}$ & $\begin{array}{c}0.0066^{* * *} \\
(0.0023)\end{array}$ \\
\hline Household size & $\begin{array}{c}-0.0160 * * * \\
(0.0006)\end{array}$ & $\begin{array}{c}-0.0049 * * * \\
(0.0002)\end{array}$ & $\begin{array}{c}0.0048 * * * \\
(0.0006)\end{array}$ & $\begin{array}{c}-0.0040 * * * \\
(0.0004)\end{array}$ \\
\hline Number of women aged 45-65 years & $\begin{array}{c}0.0173 * * * \\
(0.0020)\end{array}$ & $\begin{array}{c}0.0048 * * * \\
(0.0005)\end{array}$ & $\begin{array}{c}0.0121 * * * \\
(0.0022)\end{array}$ & $\begin{array}{c}-0.0059 * * * \\
(0.0011)\end{array}$ \\
\hline Number of elderly females & $\begin{array}{c}0.0316^{* * * *} \\
(0.0025)\end{array}$ & $\begin{array}{c}0.0034 * * * \\
(0.0009)\end{array}$ & $\begin{array}{c}0.0099 * * * \\
(0.0029)\end{array}$ & $\begin{array}{c}-0.0042 * * \\
(0.0017)\end{array}$ \\
\hline Number of elderly males & $\begin{array}{c}0.0244 * * * \\
(0.0024)\end{array}$ & $\begin{array}{c}0.0088 * * * \\
(0.0009)\end{array}$ & $\begin{array}{c}0.0206 * * * \\
(0.0030)\end{array}$ & $\begin{array}{c}0.0065 * * * \\
(0.0019)\end{array}$ \\
\hline Number of children: 0 to 2 years old & $\begin{array}{c}-0.0797 * * * \\
(0.0016)\end{array}$ & $\begin{array}{c}0.0104 * * * \\
(0.0007)\end{array}$ & $\begin{array}{c}-0.0754 * * * \\
(0.0020)\end{array}$ & $\begin{array}{c}0.0188 * * * \\
(0.0014)\end{array}$ \\
\hline Number of children: 3 to 6 years old & $\begin{array}{c}0.0056 * * * \\
(0.0013)\end{array}$ & $\begin{array}{c}0.0083 * * * \\
(0.0005)\end{array}$ & $\begin{array}{c}-0.0248 * * * \\
(0.0016)\end{array}$ & $\begin{array}{c}0.0172 * * * \\
(0.0011)\end{array}$ \\
\hline Number of children: 7 to 11 years old & $\begin{array}{c}0.0254 * * * \\
(0.0012)\end{array}$ & $\begin{array}{c}0.0087 * * * \\
(0.0004)\end{array}$ & $\begin{array}{c}-0.0043 * * * \\
(0.0014)\end{array}$ & $\begin{array}{c}0.0153^{* * * *} \\
(0.0009)\end{array}$ \\
\hline Number of children: 12 to 17 years old & $\begin{array}{c}0.0225^{* * *} * \\
(0.0011)\end{array}$ & $\begin{array}{c}0.0073 * * * \\
(0.0004)\end{array}$ & $\begin{array}{c}0.0042 * * * \\
(0.0012)\end{array}$ & $\begin{array}{c}0.0119 * * * \\
(0.0007)\end{array}$ \\
\hline Distance to district office ('100km) & $\begin{array}{l}0.0016^{*} \\
(0.0009)\end{array}$ & $\begin{array}{c}0.0002 \\
(0.0003)\end{array}$ & $\begin{array}{c}0.0173 * * * \\
(0.0016)\end{array}$ & $\begin{array}{c}0.0065^{* * * *} \\
(0.0009)\end{array}$ \\
\hline Main income: Agriculture (omitted) & & & & \\
\hline Main income: Mining/quarrying & $\begin{array}{c}-0.1186 * * * \\
(0.0103)\end{array}$ & $\begin{array}{l}-0.0048 \\
(0.0041)\end{array}$ & $\begin{array}{c}-0.0743 * * * \\
(0.0076)\end{array}$ & $\begin{array}{l}-0.0012 \\
(0.0051)\end{array}$ \\
\hline Main income: Processing/industry & $\begin{array}{c}-0.0196 * * * \\
(0.0071)\end{array}$ & $\begin{array}{l}-0.0039 \\
(0.0028)\end{array}$ & $\begin{array}{c}0.0029 \\
(0.0030)\end{array}$ & $\begin{array}{c}0.0007 \\
(0.0019)\end{array}$ \\
\hline Main income: Large trading/retail & $\begin{array}{c}-0.0953 * * * \\
(0.0069)\end{array}$ & $\begin{array}{c}-0.0294 * * * \\
(0.0034)\end{array}$ & $\begin{array}{c}-0.0218 * * * \\
(0.0021)\end{array}$ & $\begin{array}{c}-0.0185^{* * *} \\
(0.0014)\end{array}$ \\
\hline Main income: Services other than trade & $\begin{array}{c}-0.1328 * * * \\
(0.0048)\end{array}$ & $\begin{array}{c}-0.0328 * * * \\
(0.0025)\end{array}$ & $\begin{array}{c}-0.0433 * * * \\
(0.0020)\end{array}$ & $\begin{array}{c}-0.0319 * * * \\
(0.0013)\end{array}$ \\
\hline Unemployment & $\begin{array}{c}-0.0083^{* * *} * \\
(0.0006)\end{array}$ & $\begin{array}{c}0.0029 * * * \\
(0.0002)\end{array}$ & $\begin{array}{c}-0.0223 * * * \\
(0.0007)\end{array}$ & $\begin{array}{c}-0.0053 * * * \\
(0.0004)\end{array}$ \\
\hline Observations & 691,280 & 681,427 & 481,751 & 469,157 \\
\hline
\end{tabular}

Source: Authors calculations using Susenas and Podes. The marginal effects for province and age dummies can be provided on request. Significance levels $* * * \mathrm{p}<0.01, * * \mathrm{p}<0.05, * \mathrm{p}<0.1$ 
Table 5. FLFP Determinants' Annual Growth in Percentage Points

\begin{tabular}{lc} 
VARIABLES & Time trend \\
\hline Household head & 0.0020 \\
Marital status: Married & 0.0022 \\
Marital status: Divorced & 0.0000 \\
Marital status: Widowed & 0.0017 \\
Education: Primary & -0.0043 \\
Education: Lower secondary & 0.0040 \\
Education: Upper secondary & 0.0050 \\
Education: Tertiary & 0.0032 \\
Household size & -0.0273 \\
Number of elderly females & -0.0004 \\
Number of elderly males & -0.0002 \\
Presence of a potential babysitter & 0.0019 \\
Number of children: 0 to 2 years old & 0.0004 \\
Number of children: 3 to 6 years old & -0.0028 \\
Number of children: 7 to 11 years old & -0.0063 \\
Number of children: 12 to 17 years old & -0.0154 \\
Urban & 0.0073 \\
Distance to nearest district office ('100km) & 0.0063 \\
Main income: Mining/quarrying & 0.0004 \\
Main income: Processing/industry & 0.0007 \\
Main income: Large trading/retail & -0.0011 \\
Main income: Services other than trade & -0.0023 \\
Unemployment\# & -0.0014 \\
\hline
\end{tabular}


Figure 1. Female and male labour force participation over time

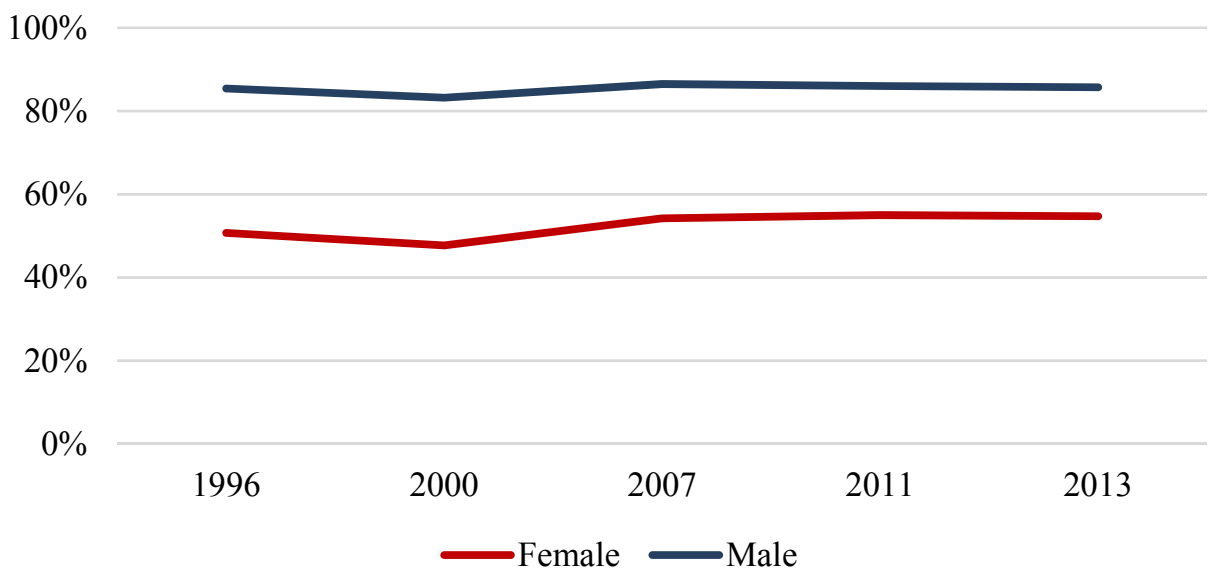

Source: Authors calculations using Susenas

Figure 2. Age and cohort effects

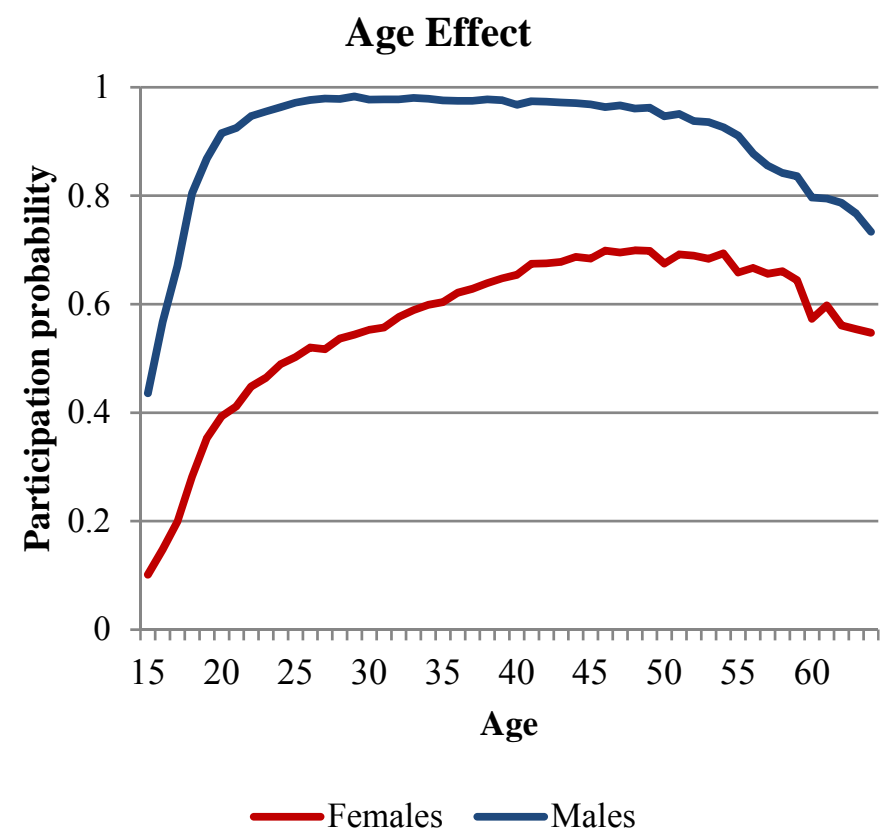

\section{Cohort Effect}

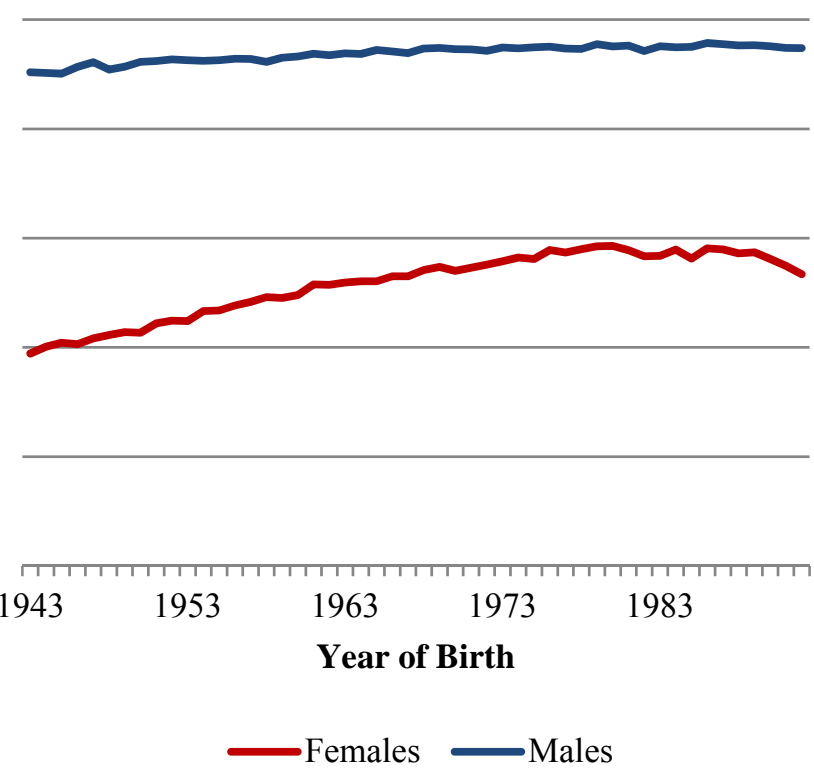

Source: Author's calculations using Susenas and Podes 
Figure 3. Age analysis of female labour force participation in Indonesia (left-hand side) and the Netherlands (right-hand side)
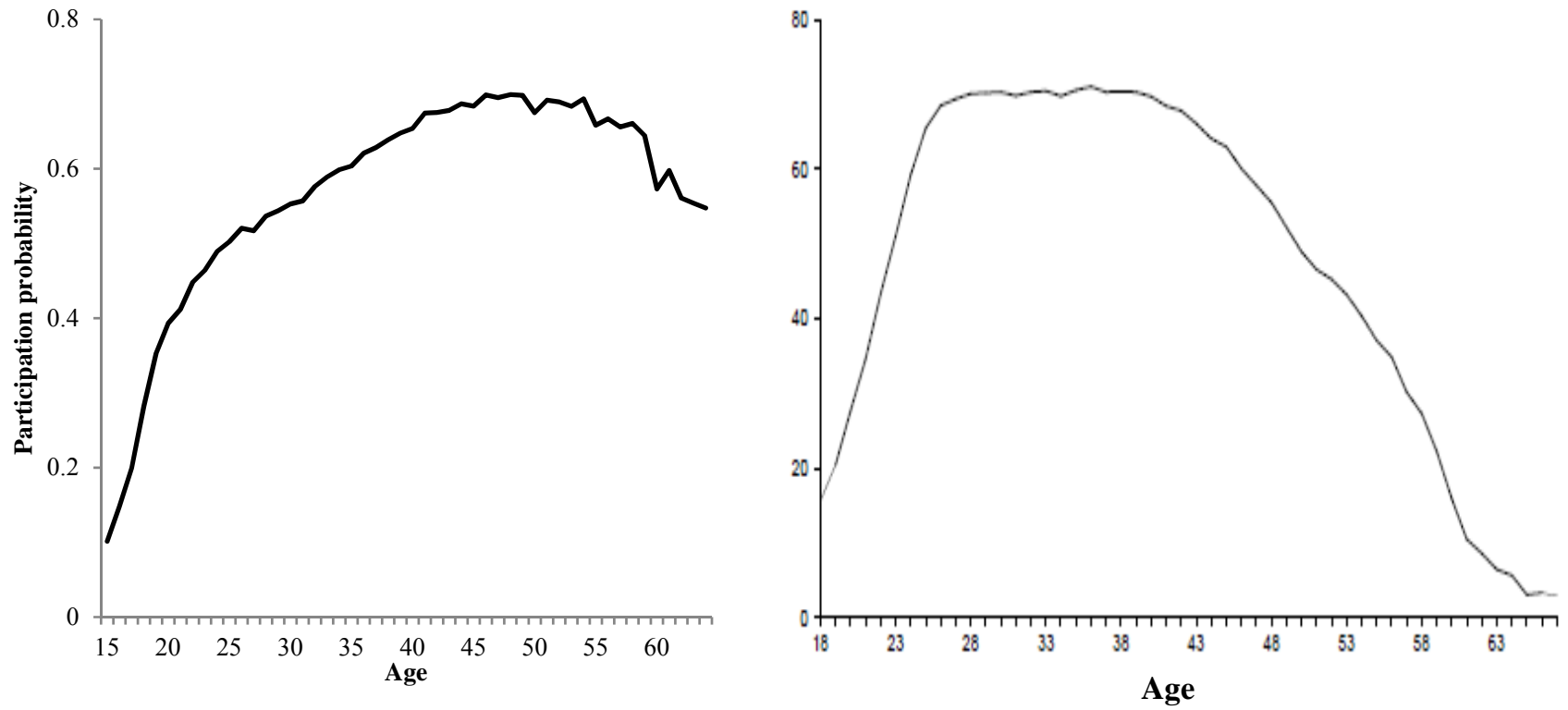

Source: Euwals et al 2011 and author's calculations using Susenas and Podes

Figure 4. Age and Cohort Effects for Rural Areas

Age Effect

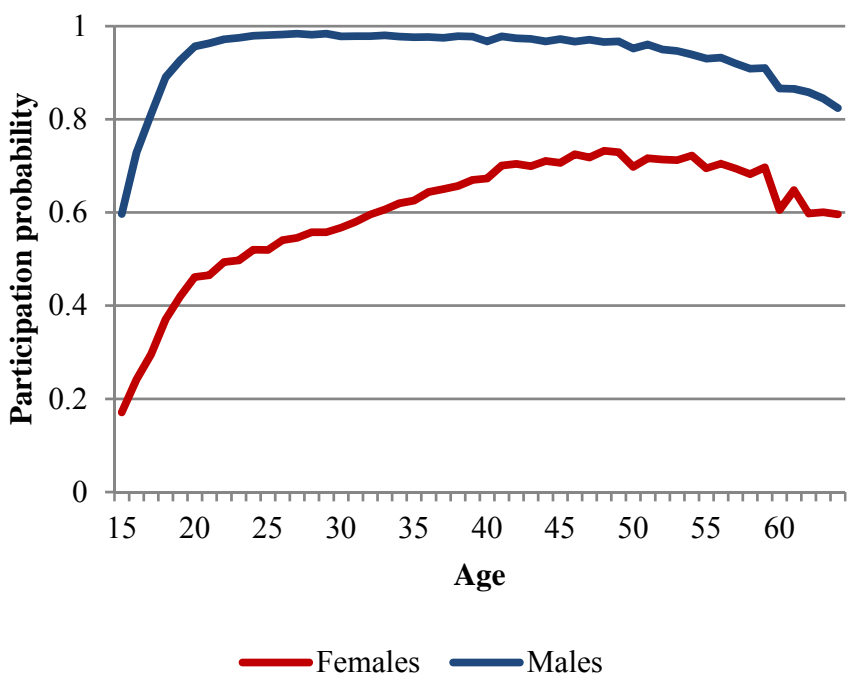

Cohort Effect

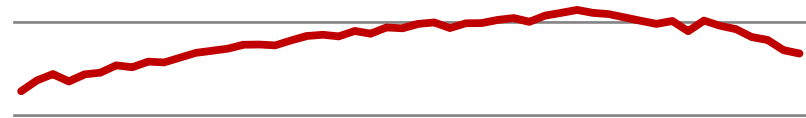

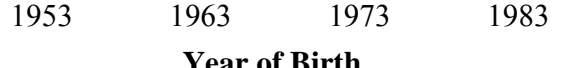

Source: Author's calculations using Susenas and Podes 
Figure 5. Age and Cohort Effects for Urban Areas

Age Effect

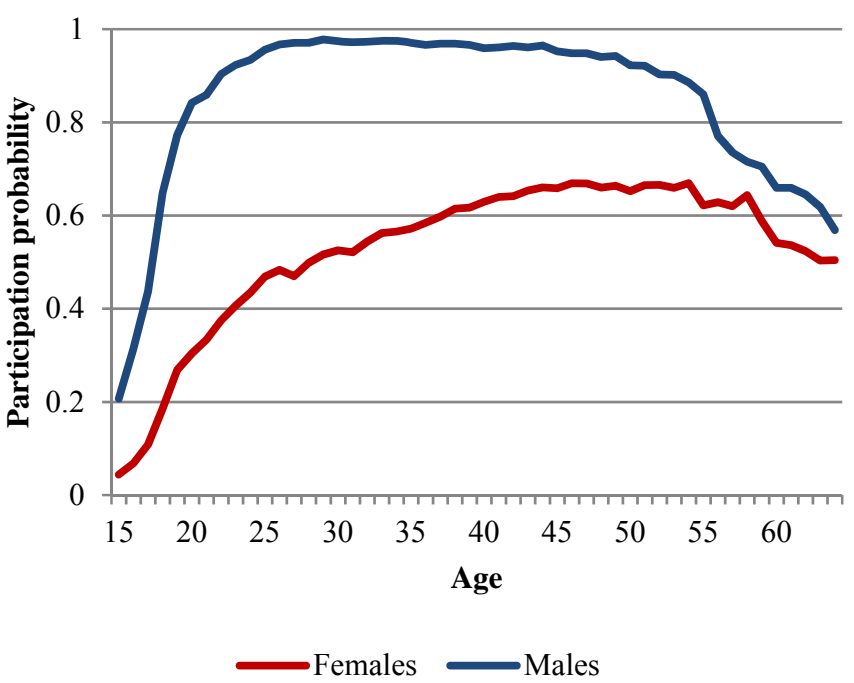

Cohort Effect
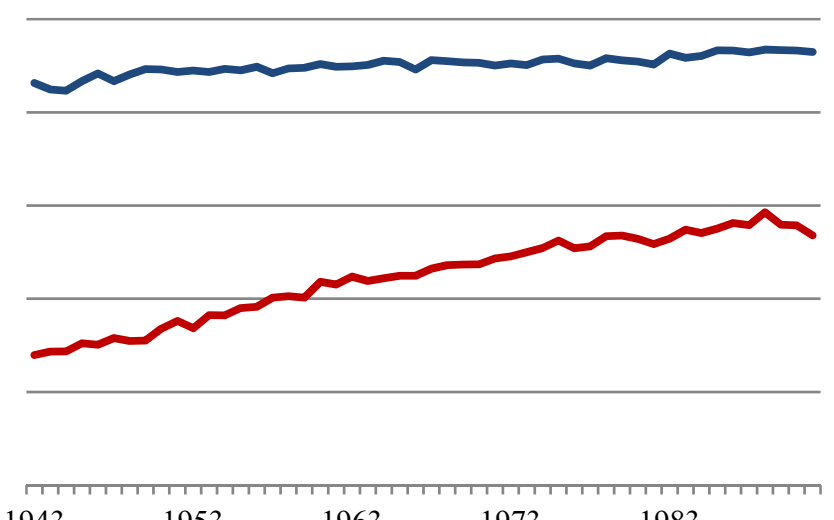

1953

1963

1973

1983

Source: Author's calculations using Susenas and Podes

Figure 6. Observed and Predicted Female Labour Force Participation

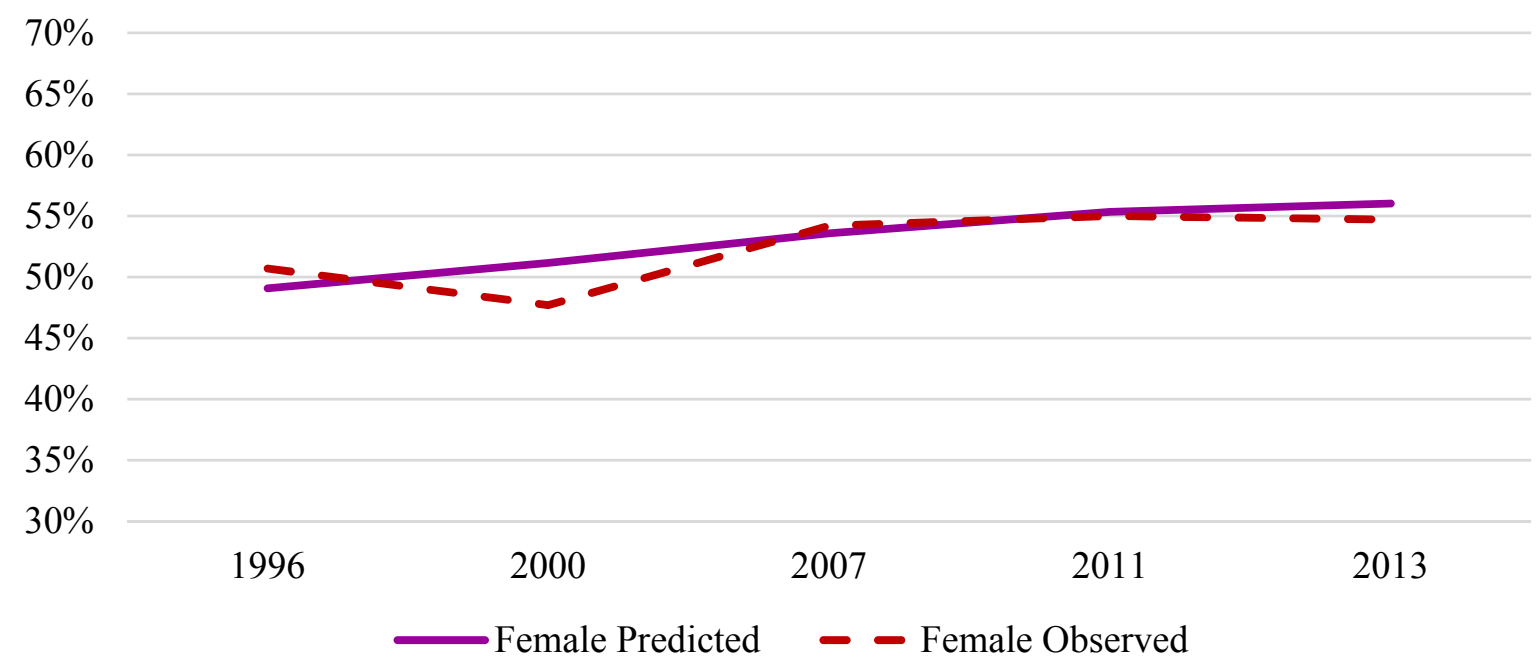


Figure 7. Projection of Female Labour Force Participation in Indonesia

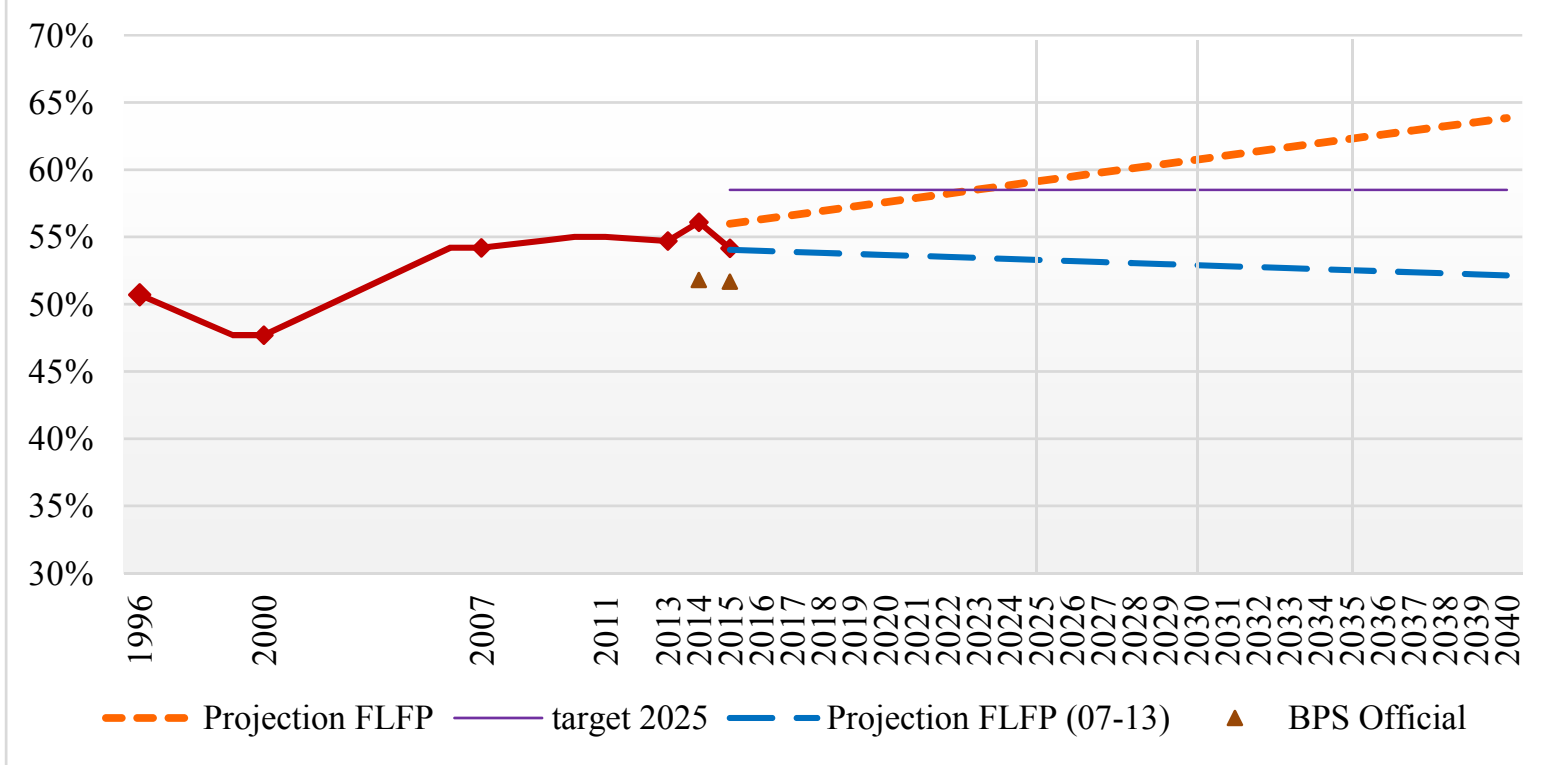




\section{Appendix}

Table A-1. Marginal effects by Java-Bali and Outer Islands Regions

\begin{tabular}{|c|c|c|c|c|}
\hline \multirow{2}{*}{ Variables } & \multicolumn{2}{|c|}{ Java-Bali Region } & \multicolumn{2}{|c|}{ Outer Islands Region } \\
\hline & Female & Male & Female & Male \\
\hline Household head & $\begin{array}{c}0.1181 * * * \\
(0.0040)\end{array}$ & $\begin{array}{c}0.0370 * * * \\
(0.0019)\end{array}$ & $\begin{array}{c}0.2093 * * * \\
(0.0032)\end{array}$ & $\begin{array}{c}0.0485 * * * \\
(0.0014)\end{array}$ \\
\hline \multicolumn{5}{|l|}{ Marital status: Single (omitted) } \\
\hline Marital status: Married & $\begin{array}{c}-0.2316 * * * \\
(0.0029)\end{array}$ & $\begin{array}{c}0.1153 * * * \\
(0.0023)\end{array}$ & $\begin{array}{c}-0.1476 * * * \\
(0.0024)\end{array}$ & $\begin{array}{c}0.0983 * * * \\
(0.0017)\end{array}$ \\
\hline Marital status: Divorced & $\begin{array}{c}-0.0467 * * * \\
(0.0059)\end{array}$ & $\begin{array}{c}0.0134 * * * \\
(0.0029)\end{array}$ & $\begin{array}{c}0.0126^{* *} \\
(0.0050)\end{array}$ & $\begin{array}{c}0.0139 * * * \\
(0.0021)\end{array}$ \\
\hline Marital status: Widowed & $\begin{array}{c}-0.2025 * * * \\
(0.0051)\end{array}$ & $\begin{array}{c}0.0286 * * * \\
(0.0024)\end{array}$ & $\begin{array}{c}-0.1586^{* * *} \\
(0.0042)\end{array}$ & $\begin{array}{c}0.0238 * * * \\
(0.0015)\end{array}$ \\
\hline \multicolumn{5}{|l|}{ Education: No schooling (omitted) } \\
\hline Education: Primary & $\begin{array}{c}-0.0363 * * * \\
(0.0022)\end{array}$ & $\begin{array}{c}0.0156 * * * \\
(0.0013)\end{array}$ & $\begin{array}{c}-0.0437 * * * \\
(0.0018)\end{array}$ & $\begin{array}{c}-0.0015^{*} \\
(0.0009)\end{array}$ \\
\hline Education: Lower secondary & $\begin{array}{c}-0.1409 * * * \\
(0.0026)\end{array}$ & $\begin{array}{c}-0.0404 * * * \\
(0.0015)\end{array}$ & $\begin{array}{c}-0.1018 * * * \\
(0.0018)\end{array}$ & $\begin{array}{c}-0.0548^{* * * *} \\
(0.0010)\end{array}$ \\
\hline Education: Upper secondary & $\begin{array}{c}-0.0734 * * * \\
(0.0027)\end{array}$ & $\begin{array}{c}0.0133 * * * \\
(0.0016)\end{array}$ & $\begin{array}{c}0.0521 * * * \\
(0.0030)\end{array}$ & $\begin{array}{c}-0.0215^{* * * *} \\
(0.0016)\end{array}$ \\
\hline Education: Tertiary & $\begin{array}{c}0.1811 * * * \\
(0.0037)\end{array}$ & $\begin{array}{c}0.0090 * * * \\
(0.0019)\end{array}$ & $\begin{array}{c}0.2893 * * * \\
(0.0025)\end{array}$ & $\begin{array}{c}-0.0122 * * * \\
(0.0018)\end{array}$ \\
\hline Household size & $\begin{array}{l}-0.0007 \\
(0.0008)\end{array}$ & $\begin{array}{c}-0.0036 * * * \\
(0.0003)\end{array}$ & $\begin{array}{c}-0.0076 * * * \\
(0.0006)\end{array}$ & $\begin{array}{c}-0.0052 * * * \\
(0.0002)\end{array}$ \\
\hline Number of women aged $45-65$ years & $\begin{array}{c}0.0162 * * * \\
(0.0023)\end{array}$ & $\begin{array}{l}-0.0009 \\
(0.0009)\end{array}$ & $\begin{array}{c}0.0150 * * * \\
(0.0019)\end{array}$ & $\begin{array}{c}0.0030 * * * \\
(0.0006)\end{array}$ \\
\hline Number of elderly females & $\begin{array}{c}0.0177 * * * \\
(0.0028)\end{array}$ & $\begin{array}{l}-0.0006 \\
(0.0013)\end{array}$ & $\begin{array}{c}0.0228 * * * \\
(0.0026)\end{array}$ & $\begin{array}{l}0.0022 * * \\
(0.0010)\end{array}$ \\
\hline Number of elderly males & $\begin{array}{c}0.0227 * * * \\
(0.0029)\end{array}$ & $\begin{array}{c}0.0073 * * * \\
(0.0015)\end{array}$ & $\begin{array}{c}0.0207 * * * \\
(0.0025)\end{array}$ & $\begin{array}{c}0.0096 * * * \\
(0.0011)\end{array}$ \\
\hline Number of children: 0 to 2 years old & $\begin{array}{c}-0.1121 * * * \\
(0.0021)\end{array}$ & $\begin{array}{c}0.0134 * * * \\
(0.0012)\end{array}$ & $\begin{array}{c}-0.0676^{* * *} \\
(0.0015)\end{array}$ & $\begin{array}{c}0.0130 * * * \\
(0.0007)\end{array}$ \\
\hline Number of children: 3 to 6 years old & $\begin{array}{c}-0.0304 * * * \\
(0.0018)\end{array}$ & $\begin{array}{c}0.0132 * * * \\
(0.0010)\end{array}$ & $\begin{array}{c}0.0000 \\
(0.0013)\end{array}$ & $\begin{array}{c}0.0102 * * * \\
(0.0006)\end{array}$ \\
\hline Number of children: 7 to 11 years old & $\begin{array}{c}-0.0028 * \\
(0.0015)\end{array}$ & $\begin{array}{c}0.0111 * * * \\
(0.0008)\end{array}$ & $\begin{array}{c}0.0171 * * * \\
(0.0011)\end{array}$ & $\begin{array}{c}0.0108 * * * \\
(0.0005)\end{array}$ \\
\hline Number of children: 12 to 17 years old & $\begin{array}{c}0.0035^{* *} \\
(0.0014)\end{array}$ & $\begin{array}{c}0.0088 * * * \\
(0.0007)\end{array}$ & $\begin{array}{c}0.0159 * * * \\
(0.0010)\end{array}$ & $\begin{array}{c}0.0083 * * * \\
(0.0004)\end{array}$ \\
\hline Distance to office ('100km) & $\begin{array}{c}0.0454 * * * \\
(0.0052)\end{array}$ & $\begin{array}{c}0.0192 * * * \\
(0.0027)\end{array}$ & $\begin{array}{c}0.0071 * * * \\
(0.0008)\end{array}$ & $\begin{array}{c}0.0023 * * * \\
(0.0003)\end{array}$ \\
\hline Main income: Agriculture (omitted) & & & & \\
\hline Main income: Mining/quarrying & $\begin{array}{c}-0.0985 * * * \\
(0.0181)\end{array}$ & $\begin{array}{c}-0.0303 * * * \\
(0.0118)\end{array}$ & $\begin{array}{c}-0.1459 * * * \\
(0.0063)\end{array}$ & $\begin{array}{c}-0.0188^{* * * *} \\
(0.0035)\end{array}$ \\
\hline Main income: Processing/industry & $\begin{array}{c}-0.0264 * * * \\
(0.0030)\end{array}$ & $\begin{array}{c}-0.0170 * * * \\
(0.0017)\end{array}$ & $\begin{array}{c}-0.0727 * * * \\
(0.0056)\end{array}$ & $\begin{array}{c}-0.0192 * * * \\
(0.0031)\end{array}$ \\
\hline Main income: Large trading/retail & $\begin{array}{c}-0.0615 * * * \\
(0.0027)\end{array}$ & $\begin{array}{c}-0.0349 * * * \\
(0.0016)\end{array}$ & $\begin{array}{c}-0.1163 * * * \\
(0.0023)\end{array}$ & $\begin{array}{c}-0.0478 * * * \\
(0.0014)\end{array}$ \\
\hline Main income: Services other than trade & $\begin{array}{c}-0.0776 * * * \\
(0.0025)\end{array}$ & $\begin{array}{c}-0.0454 * * * \\
(0.0016)\end{array}$ & $\begin{array}{c}-0.1446 * * * \\
(0.0018)\end{array}$ & $\begin{array}{c}-0.0587 * * * \\
(0.0011)\end{array}$ \\
\hline Unemployment & $\begin{array}{c}-0.0212 * * * \\
(0.0008)\end{array}$ & $\begin{array}{c}-0.0026 * * * \\
(0.0004)\end{array}$ & $\begin{array}{c}-0.0102 * * * \\
(0.0006)\end{array}$ & $\begin{array}{c}0.0028 * * * \\
(0.0002)\end{array}$ \\
\hline Observations & 466,071 & 452,007 & 706,960 & 698,577 \\
\hline
\end{tabular}

Source: Authors calculations using Susenas and Podes. The marginal effects for province and age dummies can be provided on request. Significance levels $* * * \mathrm{p}<0.01, * * \mathrm{p}<0.05, * \mathrm{p}<0.1$ 
Table A-2. Marginal Effects by Year

\begin{tabular}{|c|c|c|c|c|c|c|c|c|c|c|}
\hline \multirow{2}{*}{ Variables } & \multicolumn{2}{|c|}{1996} & \multicolumn{2}{|c|}{2000} & \multicolumn{2}{|c|}{2007} & \multicolumn{2}{|c|}{2011} & \multicolumn{2}{|c|}{2013} \\
\hline & Female & Male & Female & Male & Female & Male & Female & Male & Female & Male \\
\hline Household head & $\begin{array}{c}0.1621 * * * \\
(0.0063)\end{array}$ & $\begin{array}{c}0.0315^{* * * *} \\
(0.0025)\end{array}$ & $\begin{array}{c}0.1769^{* * *} \\
(0.0069)\end{array}$ & $\begin{array}{c}0.0439 * * * \\
(0.0032)\end{array}$ & $\begin{array}{c}0.1786^{* * * *} \\
(0.0045)\end{array}$ & $\begin{array}{c}0.0485^{* * *} \\
(0.0021)\end{array}$ & $\begin{array}{c}0.1659 * * * \\
(0.0043)\end{array}$ & $\begin{array}{c}0.0463 * * * \\
(0.0021)\end{array}$ & $\begin{array}{c}0.1447 * * * \\
(0.0092)\end{array}$ & $\begin{array}{c}0.0469 * * * \\
(0.0044)\end{array}$ \\
\hline \multicolumn{11}{|l|}{ Marital status: Single (omitted) } \\
\hline Marital status: Married & $\begin{array}{c}-0.2299 * * * \\
(0.0039)\end{array}$ & $\begin{array}{c}0.0915^{* * *} \\
(0.0029)\end{array}$ & $\begin{array}{c}-0.1792 * * * \\
(0.0045)\end{array}$ & $\begin{array}{c}0.1235^{* * * *} \\
(0.0037)\end{array}$ & $\begin{array}{c}-0.1663 * * * \\
(0.0034)\end{array}$ & $\begin{array}{c}0.0987 * * * \\
(0.0025)\end{array}$ & $\begin{array}{c}-0.1390 * * * \\
(0.0035)\end{array}$ & $\begin{array}{c}0.1117 * * * \\
(0.0026)\end{array}$ & $\begin{array}{c}-0.1444 * * * \\
(0.0073)\end{array}$ & $\begin{array}{c}0.1279 * * * \\
(0.0056)\end{array}$ \\
\hline Marital status: Divorced & $\begin{array}{c}0.0093 \\
(0.0086)\end{array}$ & $\begin{array}{c}0.0050 \\
(0.0052)\end{array}$ & $\begin{array}{c}0.0048 \\
(0.0093)\end{array}$ & $\begin{array}{c}0.0172 * * * \\
(0.0058)\end{array}$ & $\begin{array}{c}-0.0213 * * * \\
(0.0071)\end{array}$ & $\begin{array}{c}0.0113 * * * \\
(0.0031)\end{array}$ & $\begin{array}{l}-0.0111 \\
(0.0070)\end{array}$ & $\begin{array}{c}0.0142 * * * \\
(0.0028)\end{array}$ & $\begin{array}{l}-0.0096 \\
(0.0141)\end{array}$ & $\begin{array}{c}0.0247 * * * \\
(0.0047)\end{array}$ \\
\hline Marital status: Widowed & $\begin{array}{c}-0.1285 * * * \\
(0.0081)\end{array}$ & $\begin{array}{c}0.0044 \\
(0.0056)\end{array}$ & $\begin{array}{c}-0.1352 * * * \\
(0.0083)\end{array}$ & $\begin{array}{c}0.0286^{* * * *} \\
(0.0052)\end{array}$ & $\begin{array}{c}-0.1886 * * * \\
(0.0060)\end{array}$ & $\begin{array}{c}0.0237 * * * \\
(0.0022)\end{array}$ & $\begin{array}{c}-0.1632 * * * \\
(0.0060)\end{array}$ & $\begin{array}{c}0.0299 * * * \\
(0.0019)\end{array}$ & $\begin{array}{c}-0.1554 * * * \\
(0.0124)\end{array}$ & $\begin{array}{c}0.0374 * * * \\
(0.0033)\end{array}$ \\
\hline \multicolumn{11}{|l|}{ Education: No schooling (omitted) } \\
\hline Education: Primary & $\begin{array}{c}-0.0474 * * * \\
(0.0028)\end{array}$ & $\begin{array}{l}-0.0019 \\
(0.0016)\end{array}$ & $\begin{array}{c}-0.0366^{* * *} \\
(0.0033)\end{array}$ & $\begin{array}{c}0.0003 \\
(0.0022)\end{array}$ & $\begin{array}{c}-0.0435 * * * \\
(0.0027)\end{array}$ & $\begin{array}{c}0.0073 * * * \\
(0.0013)\end{array}$ & $\begin{array}{c}-0.0556 * * * \\
(0.0026)\end{array}$ & $\begin{array}{c}0.0019 \\
(0.0013)\end{array}$ & $\begin{array}{c}-0.0619 * * * \\
(0.0053)\end{array}$ & $\begin{array}{c}0.0067 * * \\
(0.0028)\end{array}$ \\
\hline Education: Lower secondary & $\begin{array}{c}-0.1604 * * * \\
(0.0036)\end{array}$ & $\begin{array}{c}-0.0781 * * * \\
(0.0027)\end{array}$ & $\begin{array}{c}-0.1616^{* * *} \\
(0.0039)\end{array}$ & $\begin{array}{c}-0.0790 * * * \\
(0.0033)\end{array}$ & $\begin{array}{c}-0.1259 * * * \\
(0.0031)\end{array}$ & $\begin{array}{c}-0.0436 * * * \\
(0.0019)\end{array}$ & $\begin{array}{c}-0.1221 * * * \\
(0.0030)\end{array}$ & $\begin{array}{c}-0.0455^{* * *} * \\
(0.0018)\end{array}$ & $\begin{array}{c}-0.1265 * * * \\
(0.0061)\end{array}$ & $\begin{array}{c}-0.0493 * * * \\
(0.0039)\end{array}$ \\
\hline Education: Upper secondary & $\begin{array}{c}0.0270^{* * * *} \\
(0.0039)\end{array}$ & $\begin{array}{c}-0.0311 * * * \\
(0.0023)\end{array}$ & $\begin{array}{c}-0.0350 * * * \\
(0.0041)\end{array}$ & $\begin{array}{c}-0.0530 * * * \\
(0.0030)\end{array}$ & $\begin{array}{c}-0.0807 * * * \\
(0.0032)\end{array}$ & $\begin{array}{c}-0.0383 * * * \\
(0.0018)\end{array}$ & $\begin{array}{c}-0.0746^{* * *} \\
(0.0030)\end{array}$ & $\begin{array}{c}-0.0382 * * * \\
(0.0017)\end{array}$ & $\begin{array}{c}-0.0840 * * * \\
(0.0060)\end{array}$ & $\begin{array}{c}-0.0364 * * * \\
(0.0035)\end{array}$ \\
\hline Education: Tertiary & $\begin{array}{c}0.2965^{* * * *} \\
(0.0059)\end{array}$ & $\begin{array}{c}0.0131 * * * \\
(0.0030)\end{array}$ & $\begin{array}{c}0.2105^{* * *} \\
(0.0078)\end{array}$ & $\begin{array}{l}-0.0037 \\
(0.0046)\end{array}$ & $\begin{array}{c}0.2012 * * * \\
(0.0040)\end{array}$ & $\begin{array}{c}-0.0097 * * * \\
(0.0024)\end{array}$ & $\begin{array}{c}0.2467 * * * \\
(0.0034)\end{array}$ & $\begin{array}{c}-0.0054 * * \\
(0.0023)\end{array}$ & $\begin{array}{c}0.2350 * * * \\
(0.0069)\end{array}$ & $\begin{array}{c}-0.0148 * * * \\
(0.0049)\end{array}$ \\
\hline Household size & $\begin{array}{c}-0.0062 * * * \\
(0.0010)\end{array}$ & $\begin{array}{c}-0.0054 * * * \\
(0.0004)\end{array}$ & $\begin{array}{c}-0.0113 * * * \\
(0.0011)\end{array}$ & $\begin{array}{c}-0.0056^{* * *} \\
(0.0005)\end{array}$ & $\begin{array}{c}-0.0052 * * * \\
(0.0008)\end{array}$ & $\begin{array}{c}-0.0038 * * * \\
(0.0003)\end{array}$ & $\begin{array}{c}-0.0061 * * * \\
(0.0009)\end{array}$ & $\begin{array}{c}-0.0040 * * * \\
(0.0004)\end{array}$ & $\begin{array}{c}-0.0102 * * * \\
(0.0018)\end{array}$ & $\begin{array}{c}-0.0060 * * * \\
(0.0008)\end{array}$ \\
\hline Number of women aged 45-65 years & $\begin{array}{c}0.0306 * * * \\
(0.0032)\end{array}$ & $\begin{array}{c}0.0063^{* * * *} \\
(0.0011)\end{array}$ & $\begin{array}{c}0.0330 * * * \\
(0.0036)\end{array}$ & $\begin{array}{l}0.0028 * \\
(0.0015)\end{array}$ & $\begin{array}{c}0.0171^{* * * *} \\
(0.0028)\end{array}$ & $\begin{array}{l}-0.0006 \\
(0.0009)\end{array}$ & $\begin{array}{c}0.0017 \\
(0.0028)\end{array}$ & $\begin{array}{l}-0.0008 \\
(0.0009)\end{array}$ & $\begin{array}{c}0.0201 * * * \\
(0.0057)\end{array}$ & $\begin{array}{c}0.0007 \\
(0.0020)\end{array}$ \\
\hline Number of elderly females & $\begin{array}{c}0.0215^{* * * *} \\
(0.0041)\end{array}$ & $\begin{array}{c}0.0001 \\
(0.0017)\end{array}$ & $\begin{array}{c}0.0245^{* * * *} \\
(0.0044)\end{array}$ & $\begin{array}{c}0.0006 \\
(0.0022)\end{array}$ & $\begin{array}{c}0.0240 * * * \\
(0.0035)\end{array}$ & $\begin{array}{c}0.0016 \\
(0.0014)\end{array}$ & $\begin{array}{c}0.0233 * * * \\
(0.0036)\end{array}$ & $\begin{array}{l}-0.0015 \\
(0.0015)\end{array}$ & $\begin{array}{c}0.0283 * * * \\
(0.0072)\end{array}$ & $\begin{array}{c}0.0014 \\
(0.0030)\end{array}$ \\
\hline Number of elderly males & $\begin{array}{c}0.0172 * * * \\
(0.0043)\end{array}$ & $\begin{array}{c}0.0086^{* * * *} \\
(0.0018)\end{array}$ & $\begin{array}{c}0.0209 * * * \\
(0.0047)\end{array}$ & $\begin{array}{c}0.0069 * * * \\
(0.0024)\end{array}$ & $\begin{array}{c}0.0269^{* * * *} \\
(0.0035)\end{array}$ & $\begin{array}{c}0.0086^{* * *} \\
(0.0016)\end{array}$ & $\begin{array}{c}0.0193 * * * \\
(0.0035)\end{array}$ & $\begin{array}{c}0.0070 * * * \\
(0.0017)\end{array}$ & $\begin{array}{c}0.0078 \\
(0.0070)\end{array}$ & $\begin{array}{c}0.0146 * * * \\
(0.0036)\end{array}$ \\
\hline Number of children: 0 to 2 years old & $\begin{array}{c}-0.0835 * * * \\
(0.0027)\end{array}$ & $\begin{array}{c}0.0158 * * * \\
(0.0014)\end{array}$ & $\begin{array}{c}-0.0735 * * * \\
(0.0032)\end{array}$ & $\begin{array}{c}0.0136^{* * *} \\
(0.0020)\end{array}$ & $\begin{array}{c}-0.0706^{* * *} \\
(0.0023)\end{array}$ & $\begin{array}{c}0.0130^{* * * *} \\
(0.0011)\end{array}$ & $\begin{array}{c}-0.0873 * * * \\
(0.0023)\end{array}$ & $\begin{array}{c}0.0098^{* * * *} \\
(0.0012)\end{array}$ & $\begin{array}{c}-0.0783 * * * \\
(0.0049)\end{array}$ & $\begin{array}{c}0.0108 * * * \\
(0.0026)\end{array}$ \\
\hline Number of children: 3 to 6 years old & $\begin{array}{l}-0.0033 \\
(0.0022)\end{array}$ & $\begin{array}{c}0.0126^{* * *} \\
(0.0011)\end{array}$ & $\begin{array}{c}-0.0065^{* *} \\
(0.0026)\end{array}$ & $\begin{array}{c}0.0134 * * * \\
(0.0016)\end{array}$ & $\begin{array}{c}-0.0067 * * * \\
(0.0019)\end{array}$ & $\begin{array}{c}0.0098^{* * * *} \\
(0.0009)\end{array}$ & $\begin{array}{c}-0.0048^{* *} \\
(0.0019)\end{array}$ & $\begin{array}{c}0.0095^{* * * *} \\
(0.0010)\end{array}$ & $\begin{array}{l}-0.0079 * \\
(0.0041)\end{array}$ & $\begin{array}{c}0.0072 * * * \\
(0.0021)\end{array}$ \\
\hline Number of children: 7 to 11 years old & $\begin{array}{c}0.0149 * * * \\
(0.0019)\end{array}$ & $\begin{array}{c}0.0129 * * * \\
(0.0009)\end{array}$ & $\begin{array}{c}0.0161 * * * \\
(0.0022)\end{array}$ & $\begin{array}{c}0.0151 * * * \\
(0.0012)\end{array}$ & $\begin{array}{c}0.0096^{* * * *} \\
(0.0017)\end{array}$ & $\begin{array}{c}0.0080^{* * * *} \\
(0.0008)\end{array}$ & $\begin{array}{c}0.0125^{* * *} \\
(0.0017)\end{array}$ & $\begin{array}{c}0.0094 * * * \\
(0.0008)\end{array}$ & $\begin{array}{c}0.0169^{* * * *} \\
(0.0035)\end{array}$ & $\begin{array}{c}0.0117 * * * \\
(0.0017)\end{array}$ \\
\hline Number of children: 12 to 17 years old & $\begin{array}{c}0.0059 * * * \\
(0.0017)\end{array}$ & $\begin{array}{c}0.0078 * * * \\
(0.0007)\end{array}$ & $\begin{array}{c}0.0162 * * * \\
(0.0020)\end{array}$ & $\begin{array}{c}0.0100^{* * * *} \\
(0.0010)\end{array}$ & $\begin{array}{c}0.0117 * * * \\
(0.0015)\end{array}$ & $\begin{array}{c}0.0084 * * * \\
(0.0006)\end{array}$ & $\begin{array}{c}0.0175^{* * *} \\
(0.0016)\end{array}$ & $\begin{array}{c}0.0077 * * * \\
(0.0007)\end{array}$ & $\begin{array}{c}0.0238^{* * * *} \\
(0.0033)\end{array}$ & $\begin{array}{c}0.0104 * * * \\
(0.0015)\end{array}$ \\
\hline
\end{tabular}




\section{Distance to office ('100km)}

Main income: Agriculture (omitted)

Main income: Mining/quarrying

Main income: Processing/industry

Main income: Large trading/retail

Main income: Services other than trade

Unemployment
(0.0012)

$-0.2362 * * *$

$(0.0172)$

$-0.0415 * * *$

$(0.0065)$

$-0.0988 * * *$

$(0.0037)$

$-0.1353 * * *$

$(0.0031)$

$-0.0407 * * *$

$(0.0006)$
$0.0022 * * *$

(0.0006)

$0.0136 * * *$

$0.0085^{* * *}$

(0.0012)

$-0.0267 * *$

$(0.0123)$

$-0.0246 * * *$

$-0.1681 * * *$

$(0.0168)$

(0.0122)

$-0.0248 * * *$

$0038)$

$(0.0025)$

$(0.0064)$

$(0.0041)$

$-0.0565^{* * *}$

$0.0277 * * 4 *$

$-0.0277^{* * *}$

$(0.0028)$

$(0.0030)$

$(0.0039)$

$-0.0674 * * *$

(0.0020)

$(0.0035)$

$(0.0026)$

$-0.1261 * * *$

(0.0027)

$0.0021 * * *$

$-0.0315^{* *}$

174,903

328,629

230,355

$0.0052 * * *$

$.0076^{* * *}$

(0.0010)

$0.0028 * * *$

$0.0079 * * *$

(0.0021)

\section{$-0.1482 * * *$ \\ $-0.0118 * *$}

$-0.1898 * *$

0.0149

$(0.0048) \quad(0.0083)$

$(0.0044)$

(0.0450)

$0.0241 * * *$

$-0.0195^{* * *}$

$(0.0021)$

$(0.0123)$

$-0.0065$

$(0.0061)$

$0.0383 * * *$

$-0.0213 * * \quad-0.0178 * * *$

$(0.0032)$

$(0.0018)$

$(0.0101)$

(0.0053)

(0.0017)

$(0.0027)$

(0.0016)

$(0.0061)$

$(0.0035)$

$-0.0029 * * *$

$0.0359 * * *$

$-0.0035 * * *$

325,065

345,598

87,040

85,973


Table A3: Probit Estimation of Female Labour Force Participation for Use in the Projections

\begin{tabular}{|c|c|c|}
\hline & All years (1996-2013) & Since $2007(2007,2011,2013)$ \\
\hline Household head & $\begin{array}{c}0.4517 * * * \\
(0.0070)\end{array}$ & $\begin{array}{c}0.4703 * * * \\
(0.0117)\end{array}$ \\
\hline \multicolumn{3}{|l|}{ Marital status: Single (omitted) } \\
\hline Marital status: Married & $\begin{array}{c}-0.4557 * * * \\
(0.0049)\end{array}$ & $\begin{array}{c}-0.4388 * * * \\
(0.0083)\end{array}$ \\
\hline Marital status: Divorced & $\begin{array}{l}-0.0079 \\
(0.0095)\end{array}$ & $\begin{array}{c}-0.0404 * * \\
(0.0161)\end{array}$ \\
\hline Marital status: Widowed & $\begin{array}{c}-0.4245 * * * \\
(0.0087)\end{array}$ & $\begin{array}{c}-0.4762 * * * \\
(0.0143)\end{array}$ \\
\hline \multicolumn{3}{|l|}{ Education: No schooling (omitted) } \\
\hline Education: Primary & $\begin{array}{c}-0.1069 * * * \\
(0.0034)\end{array}$ & $\begin{array}{c}-0.1049 * * * \\
(0.0061)\end{array}$ \\
\hline Education: Lower secondary & $\begin{array}{c}-0.3067 * * * \\
(0.0042)\end{array}$ & $\begin{array}{c}-0.2832 * * * \\
(0.0071)\end{array}$ \\
\hline Education: Upper secondary & $\begin{array}{c}-0.0868 * * * \\
(0.0043)\end{array}$ & $\begin{array}{c}-0.1478 * * * \\
(0.0073)\end{array}$ \\
\hline Education: Tertiary & $\begin{array}{l}0.7147 * * * \\
(0.0068)\end{array}$ & $\begin{array}{c}0.6466^{* * * *} \\
(0.0107)\end{array}$ \\
\hline Household size & $\begin{array}{c}-0.0122 * * * \\
(0.0011)\end{array}$ & $\begin{array}{c}-0.0071 * * * \\
(0.0019)\end{array}$ \\
\hline Number of women aged 45-65 years & $\begin{array}{c}0.0513 * * * \\
(0.0048)\end{array}$ & $\begin{array}{c}0.0456 * * * \\
(0.0081)\end{array}$ \\
\hline Number of elderly females & $\begin{array}{c}0.0522 * * * \\
(0.0048)\end{array}$ & $\begin{array}{c}0.0491 * * * \\
(0.0080)\end{array}$ \\
\hline Number of elderly males & $\begin{array}{l}0.0373 * * * \\
(0.0037)\end{array}$ & $\begin{array}{c}0.0210^{* * * *} \\
(0.0063)\end{array}$ \\
\hline Number of children: 0 to 2 years old & $\begin{array}{c}-0.2065 * * * \\
(0.0031)\end{array}$ & $\begin{array}{c}-0.1992 * * * \\
(0.0053)\end{array}$ \\
\hline Number of children: 3 to 6 years old & $\begin{array}{c}-0.0221 * * * \\
(0.0026)\end{array}$ & $\begin{array}{c}-0.0319 * * * \\
(0.0045)\end{array}$ \\
\hline Number of children: 7 to 11 years old & $\begin{array}{c}0.0283 * * * \\
(0.0022)\end{array}$ & $\begin{array}{c}0.0163 * * * \\
(0.0039)\end{array}$ \\
\hline Number of children: 12 to 17 years old & $\begin{array}{l}0.0316^{* * *} \\
(0.0021)\end{array}$ & $\begin{array}{c}0.0297 * * * \\
(0.0036)\end{array}$ \\
\hline Urban & $\begin{array}{c}-0.2403 * * * \\
(0.0036)\end{array}$ & $\begin{array}{c}-0.2589 * * * \\
(0.0060)\end{array}$ \\
\hline Distance to office ('100km) & $\begin{array}{c}0.0152 * * * \\
(0.0020)\end{array}$ & $\begin{array}{c}0.0129 * * * \\
(0.0036)\end{array}$ \\
\hline Main income: Agriculture (omitted) & & \\
\hline Main income: Mining/quarrying & $\begin{array}{c}-0.2425 * * * \\
(0.0157)\end{array}$ & $\begin{array}{c}-0.2722 * * * \\
(0.0288)\end{array}$ \\
\hline Main income: Processing/industry & $\begin{array}{r}0.0160 * * \\
(0.0068)\end{array}$ & $\begin{array}{c}0.0237 * * \\
(0.0116)\end{array}$ \\
\hline Main income: Large trading/retail & $\begin{array}{c}-0.0819 * * * \\
(0.0050)\end{array}$ & $\begin{array}{c}-0.0815 * * * \\
(0.0084)\end{array}$ \\
\hline Main income: Services other than trade & $\begin{array}{c}-0.1491 * * * \\
(0.0045)\end{array}$ & $\begin{array}{c}-0.1447 * * * \\
(0.0076)\end{array}$ \\
\hline Unemployment & $\begin{array}{c}-0.0141 * * * \\
(0.0017)\end{array}$ & $\begin{array}{c}-0.0146^{* *} \\
(0.0070)\end{array}$ \\
\hline Constant & $\begin{array}{c}-0.4532 * * * \\
(0.0249)\end{array}$ & $\begin{array}{c}-0.4119 * * * \\
(0.0413)\end{array}$ \\
\hline Observations & $1,173,031$ & 415,669 \\
\hline
\end{tabular}

Notes: Standard errors in parentheses, $* * * p<0.01, * * p<0.05, * \mathrm{p}<0.1$. Estimations include province, age and date of birth fixed effects. \# Unemployment rate by region. 
Figure A-1. Age and Cohort Effects for Rural Java-Bali Region

Age Effect

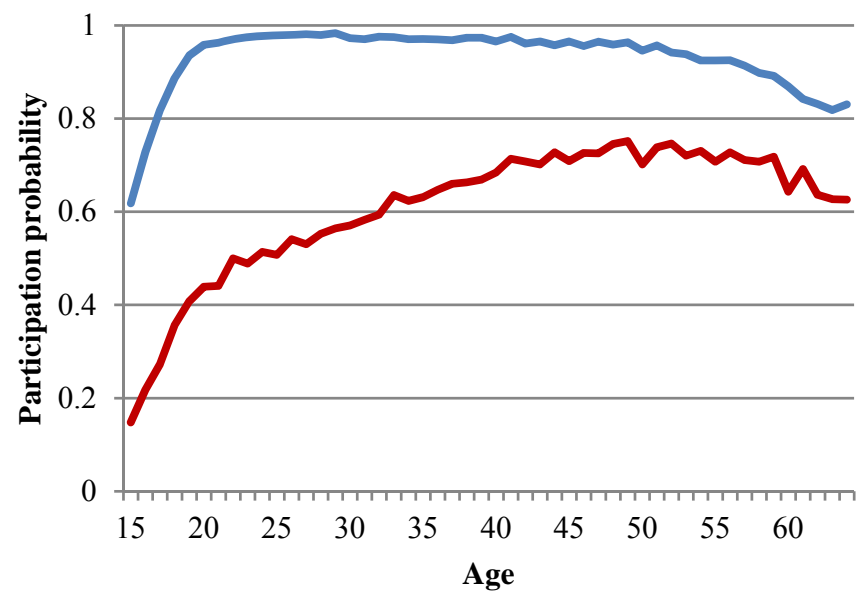

$\longrightarrow$ Females $\longrightarrow$ Males
Cohort Effect
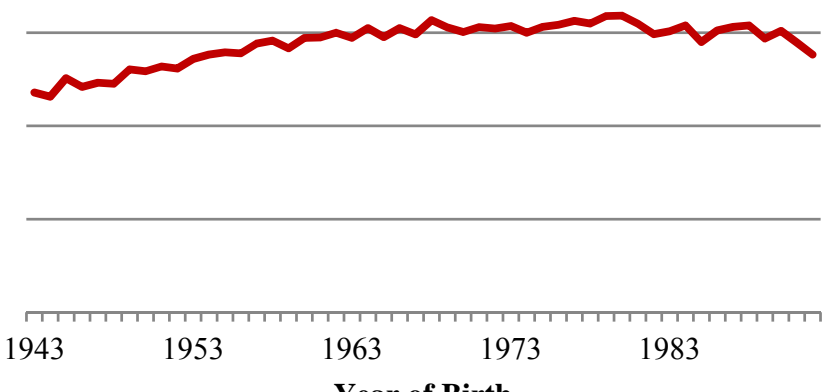

Year of Birth

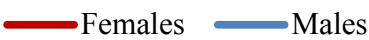

Source: Author's calculations using Susenas and Podes

Figure A-2. Age and Cohort Effects for Urban Java-Bali Region

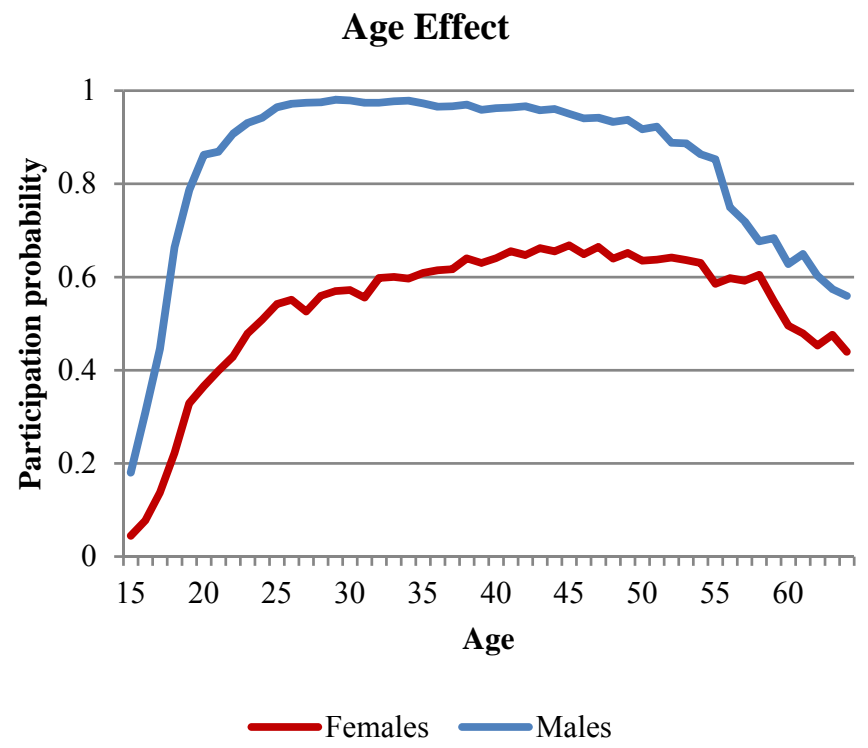

Cohort Effect

Source: Author's calculations using Susenas and Podes 
Figure A-3. Age and Cohort Effects for Rural Outer Islands Region

Age Effect

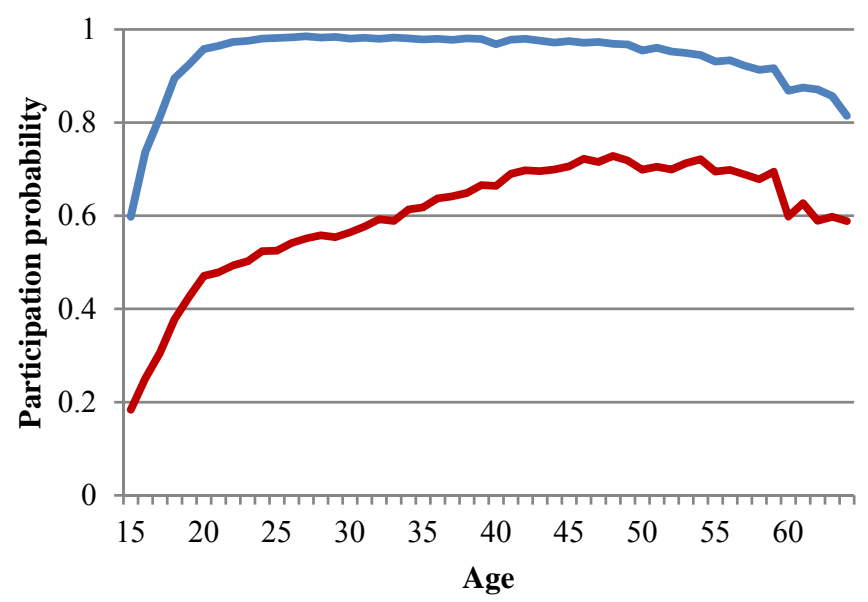

$\longrightarrow$ Females $\longrightarrow$ Males
Cohort Effect

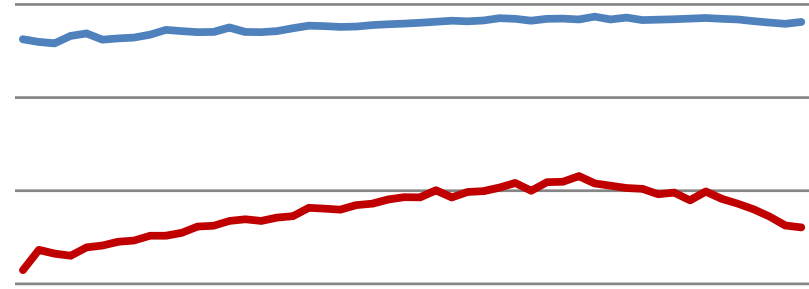

$1963 \quad 1973$

Females Males

Source: Author's calculations using Susenas and Podes

Figure A-4. Age and Cohort Effects for Urban Outer Islands Region

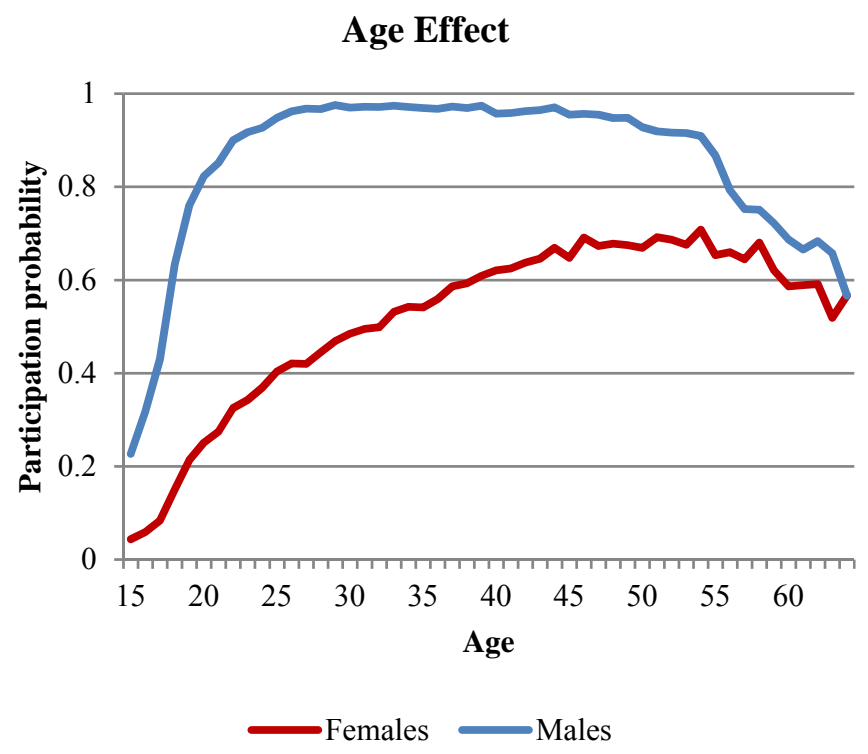

Cohort Effect

Source: Author's calculations using Susenas and Podes 
Figure A-5. Age and Cohort Effects by Marital Status

Age Effect

Cohort Effect
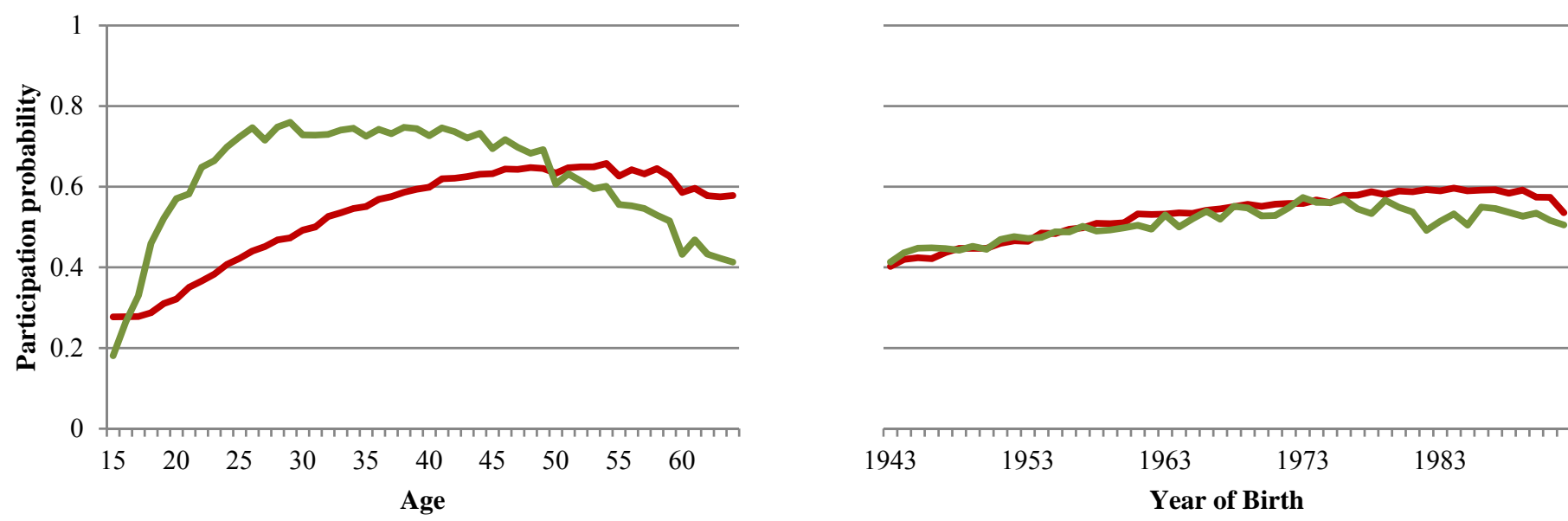

1973

1983

Year of Birth

-Female married $\quad$ Female non-married

Source: Author's calculations using Susenas and Podes

Notes: Not married includes single, divorced and widowed

Figure A-6. Age and Cohort Effects for Females by Educational

Attainment

Age Effect

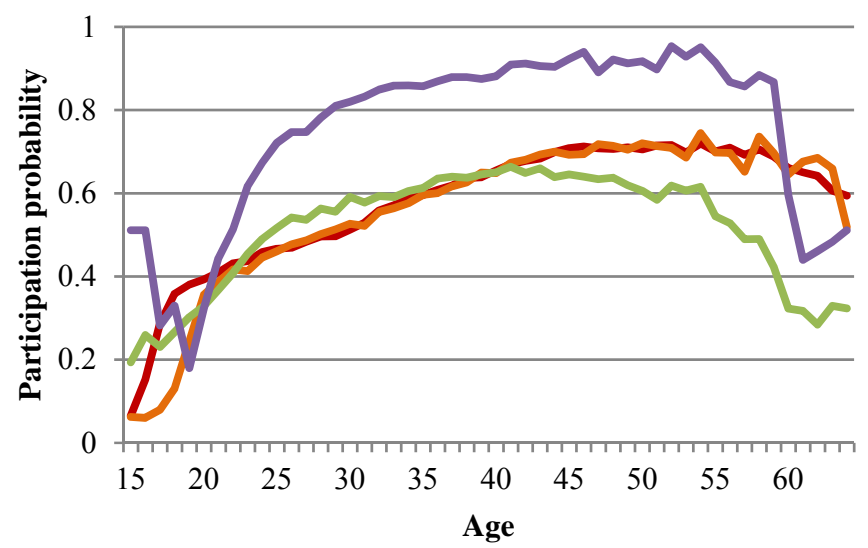

$\begin{array}{ll}\longrightarrow \text { Primary } & \text { Lower-secondary } \\ \text { Upper-secondary } & \text { Tertiary }\end{array}$
Cohort Effect

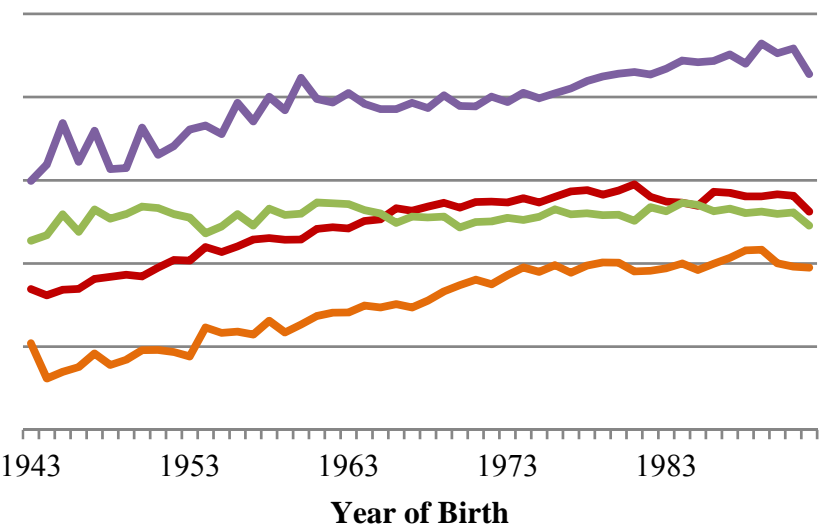

$\begin{array}{ll}\text { Primary } & \text { Lower-secondary } \\ \text { Upper-secondary } & \text { Tertiary }\end{array}$

Source: Author's calculations using Susenas and Podes 
Figure A-7. Age and Cohort Effects for Females by Number of Children

Age Effect

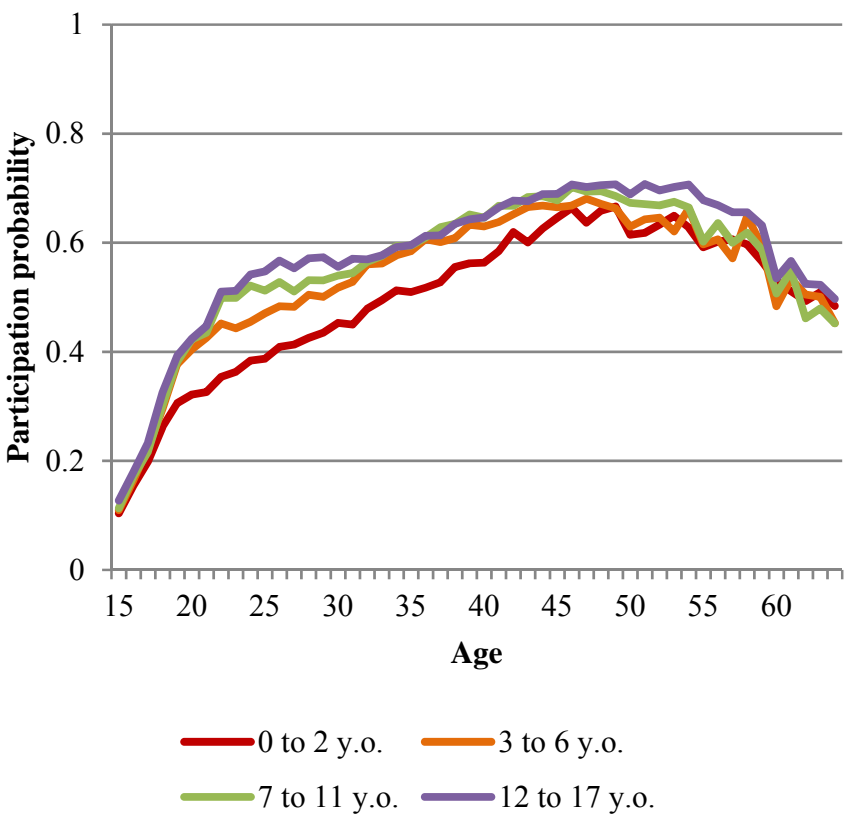

Cohort Effect

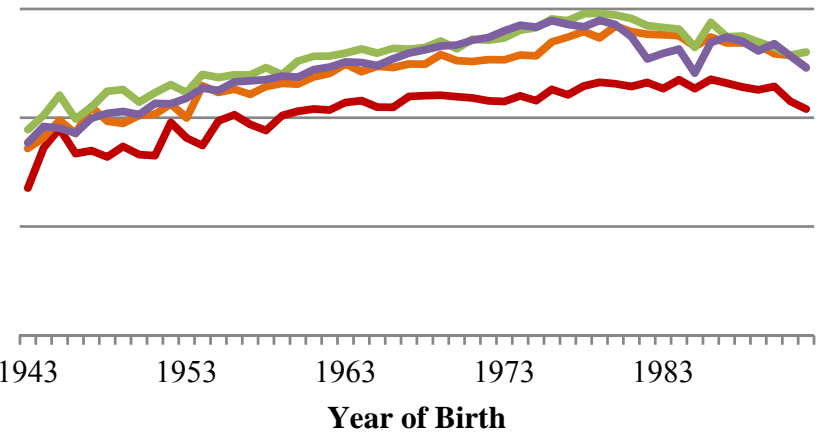

Source: Author's calculations using Susenas and Podes

Figure A-8. Age and Cohort Effects for Females by Village Main Income Type

Age Effect

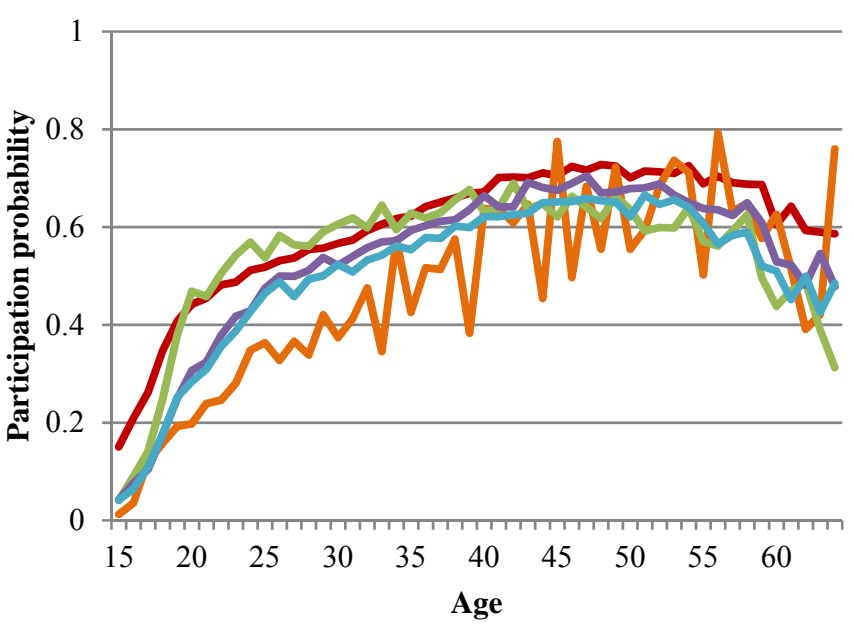

Agriculture
Processing/industry

Mining/quarrying

Large trading/retail

Services/other trade
Cohort Effect
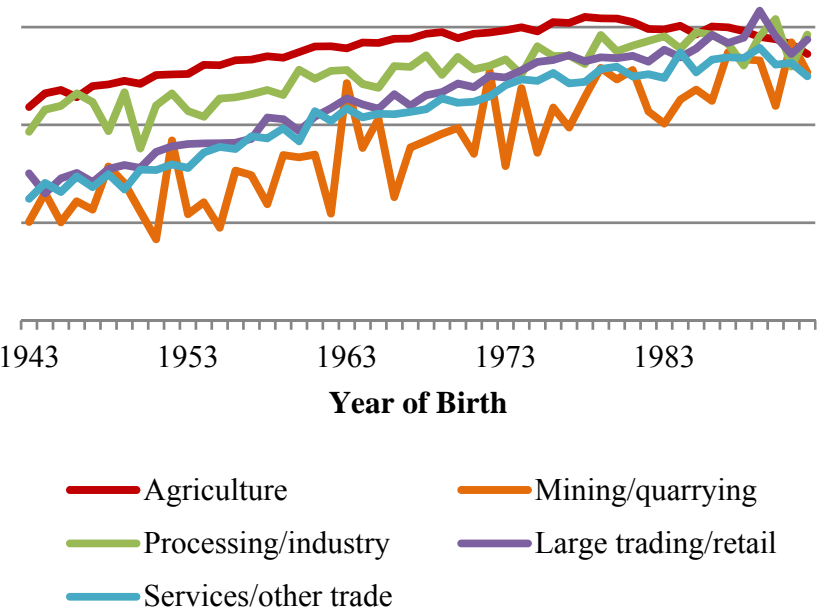

Source: Author's calculations using Susenas and Podes. 